\title{
Tooth Organ Engineering: Biological Constraints Specifying Experimental Approaches
}

\author{
"Sabine Kuchler-Bopp"1,2, Laetitia Keller1,2, Anne Poliard ${ }^{3}$ and Herve Lesot ${ }^{1,2}$ \\ ${ }^{1}$ INSERM UMR977, Université de Strasbourg, \\ ${ }^{2}$ Faculté de Chirurgie Dentaire, Université de Strasbourg, \\ ${ }^{3}$ EA 2496, Université Paris Descartes, Faculté de Chirurgie Dentaire, Montrouge,
}

France

\section{Introduction}

Basically, two types of approaches are currently being developed for tooth engineering. The first one consists in the engineering of dental constituents, such as the periodontium, the pulp/dentin, or the enamel/dentin complexes (Duan et al., 2011; Honda et al., 2009; Huang, 2009; Park et al., 2010). In parallel with these experiments of tissue engineering, attempts are also made to reconstruct a whole tooth (Arany et al., 2009; Honda et al., 2008; Hu et al., 2006a; Komine et al., 2007; Nakao et al., 2007; Ohazama et al., 2004). Most of this chapter will consider the second goal, and only use data from tooth tissue engineering, when they bring information about the cellular or molecular mechanisms that are involved and/or about the specific constraints, which they may illustrate.

Few groups are interested in a biomimetic approach to engineer a whole tooth, including crown, roots, and periodontium by using cultured cell-cell re-associations and trying to recapitulate the successive steps of tooth development (Arany et al., 2009; Honda et al., 2008; $\mathrm{Hu}$ et al., 2006a; Nakao et al., 2007; Ohazama et al., 2004). Specific questions arising from this research concern the experimental design, and the search for easily available cell sources. The panel of approaches is progressively restricted by two types of biological constraints: those specifically related to tooth functionality and those related to more general biological aspects such as the maintenance of the cell heterogeneity in the dental mesenchyme and in the periodontium, keeping the gradients of cell differentiation and their 3D-geometry, or the maintenance of the cell kinetic parameters to ensure the differential cusp timing and growth. These complementary points will be discussed in light of parallel approaches being developed by different groups.

\section{Abbreviations}

BMSCs: bone marrow stem cells, CGHT: chondroitin-6-sulfate/gelatin/hyaluronate tricopolymer, CL: cervical loop, DM: dental mesenchyme, DEJ: dentin-enamel junction, DFPCs: dental follicle precursor cells, DP; dental pulp, DPSCs: dental pulp stem cells, DRG: dorsal root

\footnotetext{
* Sabine Kuchler-Bopp and Laetitia Keller contributed equally to this work
} 
ganglia, ECM: extracellular matrix, ED: embryonic day, FGF: fibroblast growth factor, GFP: green fluorescent protein, HA/TCP: hydroxyapatite/tricalcium phosphate, IDE: inner dental epithelium, iDPSCs: induced dental pulp stem cells, iPSCs: induced pluripotent stem cells, MSCs: mesenchymal stem cells, NF-PLLA: nanofibrous-poly-Llactic acid, ODE: outer dental epithelium, PDLSCs: periodontal ligament stem cells, PEK: primary enamel knot, PGA: polyglycolic acid, PLGA: poly-L-lactate-co-glycolate, PLLA: poly-L-lactate, SBP: stromal bone producing cells, SCAPs: stem cells from the apical papilla, Shh; Sonic hedgehog, SI: stratum intermedium, SHEDs: stem cells from human exfoliated deciduous teeth, SPCs side population cells, SR: stellate reticulum, SMA: smooth muscle actin, $\beta$-TCP: $\beta$-tricalcium phosphate.

\section{Engineering a whole tooth using embryonic dental cells}

Embryonic dental cells are commonly used as they allow a full tooth development from cellcell re-associations (Honda et al., 2008; Hu et al., 2005; Nakao et al., 2007). A two stages methodology has been developed, where cell-cell re-associations are cultured in vitro before implantation in adult mice (Fig. 1; Hu et al., 2006a; Nakao et al., 2007). The in vitro culture allowed epithelial histogenesis, initiation of crown morphogenesis and odontoblasts to become post-mitotic (Fig. 2A, C, D). Ameloblast functional differentiation as well as root and periodontal tissue development started during the implantation period (Fig. 2B, E). This two steps method is quite well established and has been used with either dental or non-dental cell sources (Arany et al., 2009; Honda et al., 2007; Nakao et al., 2007; Ohazama et al., 2004).

\subsection{Epithelial histogenesis and crown morphogenesis}

During tooth development, the primary enamel knot (PEK), a morphogenetic center controlling crown morphogenesis, transiently forms in the enamel organ (Jernvall \& Thesleff, 2000). The histogenesis and functionalization of this structure in cell-cell reassociations is thus an essential step to be achieved. Using embryonic dental cells, the PEK reproducibly formed during early stages of the re-association in vitro (Fig. 2C) and was characterized by the condensation of non dividing cells in the epithelium, their expression of Shh and a local concentration of apoptosis (Hu et al., 2005). Four days after this PEK specification, cusps developed, showing that this structure was functional (Fig. 2A). However, up to now, this could not be achieved when using bone marrow cells instead of embryonic dental mesenchymal cells (Nait Lechguer et al., 2009). It was shown that the mesenchyme specifies epithelial histogenesis (Lesot \& Brook, 2009; Nait Lechguer et al., 2009) and that the number of mesenchymal cells used for re-association is a critical parameter in determining the number of cusps (Hu et al., 2006a). In contrast with bone marrow cells (Ohazama et al., 2004), the potentialities of the embryonic dental mesenchymal cells to stimulate tooth formation are lost in vitro (Keller et al., 2011). Attempts were made to recover it by pre-culturing these cells in the presence of FGF2 (Arany et al., 2009; Keller et al., 2011). Like FGF2, the use of FGF1 or FGF8 or their combination did not allow tooth formation (data not shown). In cell-cell re-associations, the potentialities of cells to engage in tooth development seem to be revealed during the first few hours of co-culture, several days before it became histologically visible. There is no molecular marker to anticipate the fate of cells in re-associations and to predict whether they can engage in tooth formation. On the other hand, there is no published example where cell-cell re-associations could engage in early stage of tooth re-formation and stop thereafter, as observed in several mutants where the bud to cap transition is critical (Jernvall \& Thesleff, 2000; Peters \& Balling, 1999). 


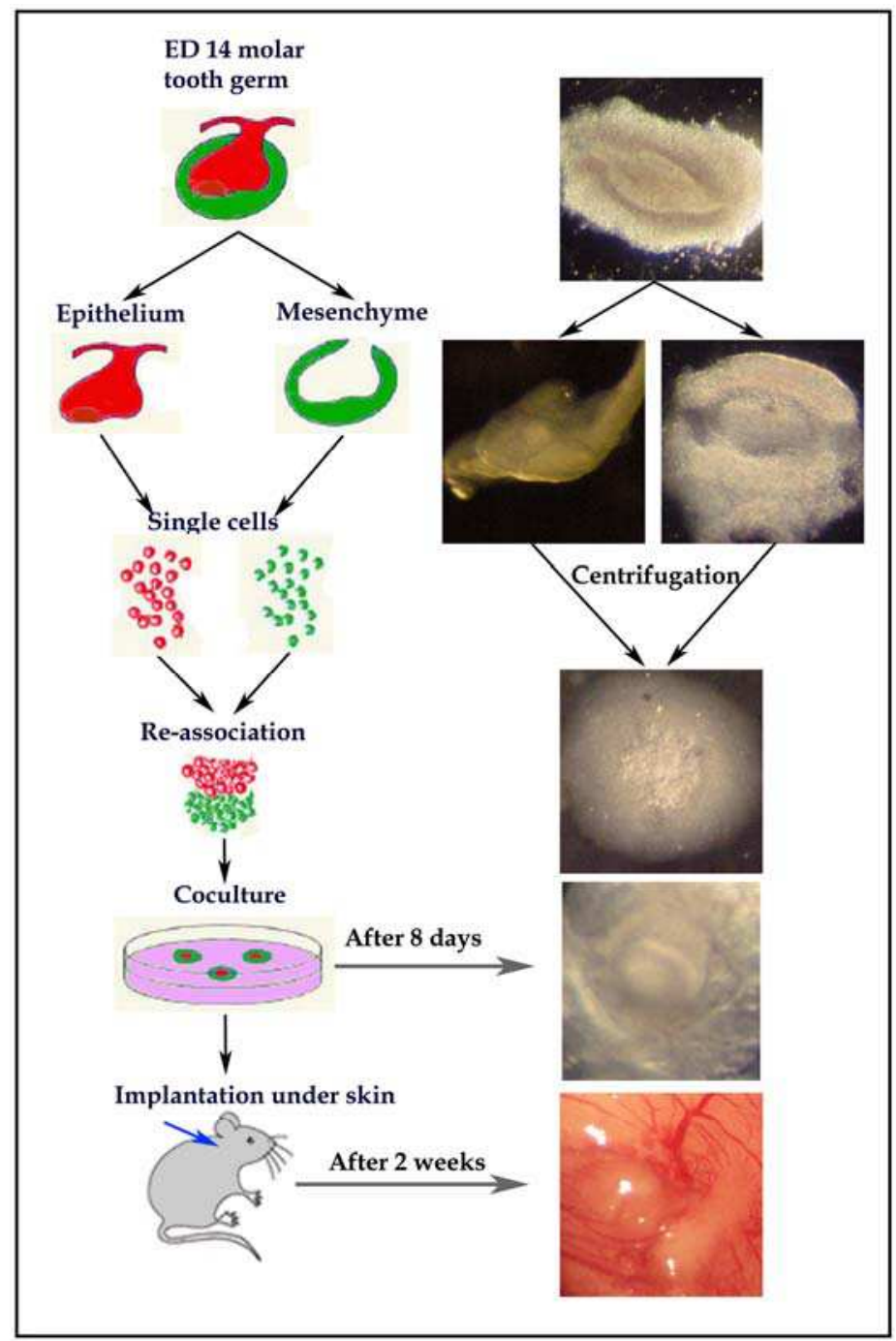

Fig. 1. Schematic representation of the experimental procedures.

The mandibular first molars were dissected from ICR embryos at embryonic day (ED) 14 . All procedures with animals were in compliance with the recommendations of the European Economic Community (86/609/CEE) on the use and care of laboratory animals. The dental epithelium and mesenchyme were dissociated by using $1 \%$ trypsin in DMEM-F12 at $4^{\circ} \mathrm{C}$ for $30 \mathrm{~min}$. After separation, the dental epitheliums and mesenchymes were dissociated into cells by centrifugation through $70 \mu \mathrm{m}$ nylon filters. Epithelial and mesenchymal cells were then pelleted by centrifugation at $9000 \mathrm{~g}$., fragments of each pellet were re-associated and cultured for 8 days. After 8 days in vitro, the re-associations were implanted between skin and muscles behind the ears in ICR or GFP adult mice. The implantations were maintained for up to two weeks 


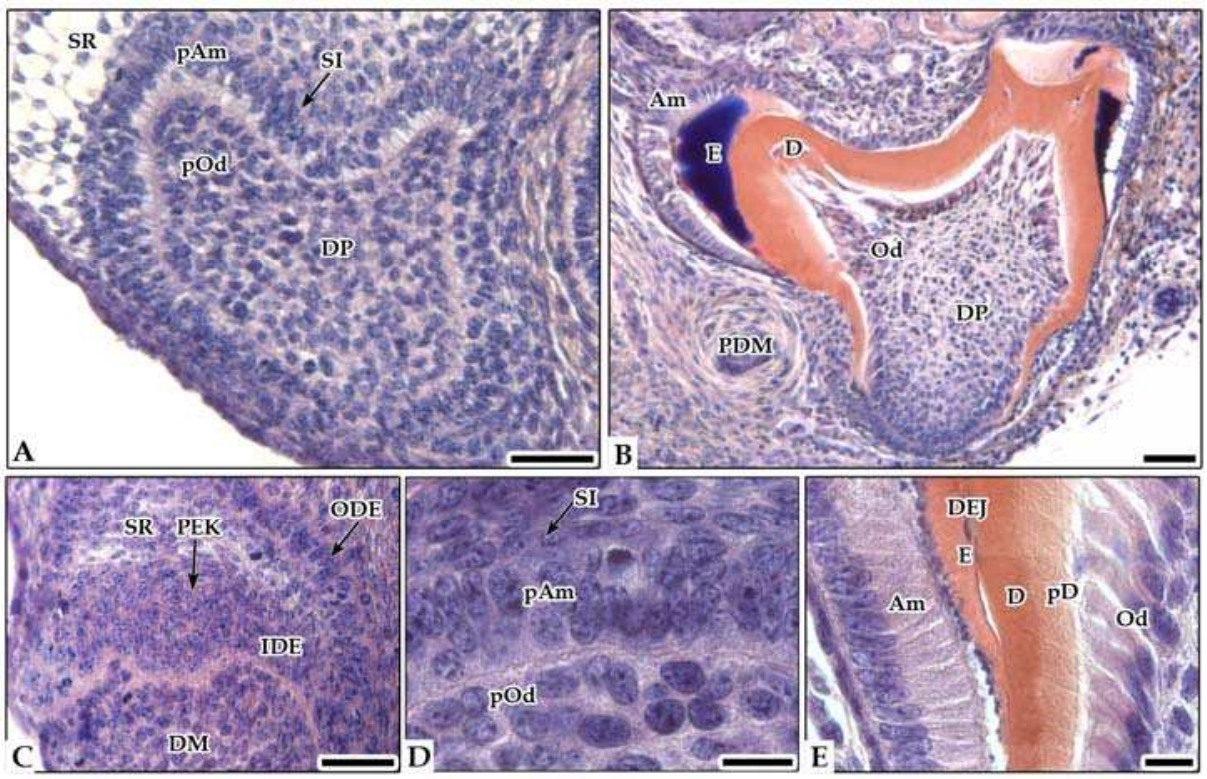

Fig. 2. Histology of dental epithelial and mesenchymal cell-cell re-associations cultured for 4 days (C), 8 days (A, D) and implanted for 2 weeks under skin (B, E).

For histology, samples were fixed in Bouin-Hollande, embedded in paraffin, and $5 \mu \mathrm{m}$ serial sections were stained with Mallory. Implants were demineralized in 4.3\% EDTA before their inclusion in paraffin. At four days in culture, the PEK was visible (C) and cusps developed after 8 days (A). After 8 days in culture, preodontoblasts and postmitotic odontoblasts are facing preameloblasts (D). After implantation (B, E) ameloblasts became functional, gradient of differentiation and mineralization of the dental matrices were achieved. Am: ameloblasts, CL: cervical loop, D: dentin, DEJ: dentin-enamel junction, DM: dental mesenchyme, DP: dental pulp, E: enamel, IDE: inner dental epithelium, ODE: outer dental epithelium, Od: odontoblasts, pAm: preameloblasts, pD: predentin, PDM: peridental mesenchyme, PEK:primary enamel knot, pOd: preodontoblasts, SI: stratum intermedium, SR: stellate reticulum. Bars $=10 \mu \mathrm{m}(\mathrm{D}, \mathrm{E})$ and $40 \mu \mathrm{m}(\mathrm{A}, \mathrm{B}, \mathrm{C})$

The in vitro culture of embryonic dental cell-cell re-associations allowed the rapid deposition of a basement membrane at the epithelial-mesenchymal junction. A complete epithelial histogenesis could be achieved within 4 to 6 days, including the inner and outer dental epitheliums, the stellate reticulum and, later, the stratum intermedium (Fig. 2A, C; Hu et al., 2005). This stratum intermedium plays an essential role in the functional differentiation of ameloblasts (Lesot \& Brook, 2009; Nait Lechguer et al., 2011; Yoshida et al., 2010). Only in one report, non polarized ameloblasts-like cells expressing amelogenin appeared to be generated in the absence of a stratum intermedium (Honda \& Hata, 2010). However, it is not known whether these cells, after longer implantation periods might indeed lead to the formation of organized enamel crystals.

However, it remains to be determined whether and how far such potentialities can be maintained at later embryonic stages and also in the adult (Keller et al., 2011). Keratinization, leading to cyst formation, is indeed a major problem arising when culturing 
cell-cell re-associations, or even after implantation (Arany et al., 2009; Honda et al., 2008; Komine et al., 2007). Such cysts may then mechanically interfere with tooth morphogenesis. It is not clear yet, whether embryonic dental epithelial cells can be expanded in vitro, without loosing their potentialities, as observed with mesenchymal cells (Keller et al., 2011).

\subsection{Functional cell differentiation}

During tooth development, the differentiation of odontoblasts and ameloblasts occurs in a progressive way. Gradients in the cytological and functional differentiation of the two cell types warrant the adhesion of enamel to dentin. It also allows the further growth of the tooth from the late bell stage, while it is already impaired at the tip of the cusps by the matrix accumulated there. In the absence of interposed scaffold, the exchanges between the epithelial and ecto-mesenchymal compartments can occur directly and the planar signaling within the preodontoblast-odontoblast cell layer can have a direct echo on the preameloblast-ameloblast layer (Ruch et al., 1995). It is not known how far this is transmitted to the stratum intermedium. In the absence of scaffold, gradients of differentiation and the progressive polarized deposition and mineralization of the dental matrices could be reproduced in cultured and implanted cell-cell re-associations (Fig. 2B, E). Recently, the organization of these mineralized matrices has been investigated (Honda et al., 2008; Nait Lechguer et al., 2011). Tooth-specific constraints include the necessity to get a correct mineralization of the matrices (dentin, enamel and cementum), which itself requires a good vascularization of the reconstructed organ (Fig. 4A-D; Nait Lechguer et al., 2008, 2011). Ultimately, the quality of the dentin-enamel junction (DEJ) and the orientation of the crystals in each matrix will determine the functionality of the tooth (Katz et al., 2007). The DEJ has been viewed as a connector between two matrices with distinct mechanical properties. The quality of this DEJ, with its own mechanical and bonding specificities, is thus a critical parameter to be preserved in tooth engineering. The risk of interfering with the integrity of the DEJ might then represents a major limitation in the use of scaffolds designed to shape engineered teeth (Xu et al., 2008).

Depending on the region of the dental mesenchyme during tooth development, local specificities were observed, which supported differential timings in cusp formation, their individual kinetic of development, and their final different sizes (Lesot et al., 1999). These were suggested to result from regional variations in cell proliferation kinetics, thus requiring sophisticated mechanisms to coordinate these events in the ecto-mesenchyme and neighbor inner dental epithelium (Lesot et al., 2001; Lisi et al., 2003). These parameters have not been investigated in the case of cultured and implanted cell-cell re-associations, although they would determine the crown shape. To avoid probably very difficult questions, it was suggested to put efforts mainly on root engineering allowing then the implantation of an artificial crown (Volponi et al., 2010).

\subsection{Root formation}

More and more, the root appears as the key point in tooth engineering because its functionality is related to tooth anchoring as well as in the mediation of tooth movement in the jaw. For this reason, it is important to avoid ankylosis. As determining tooth functionality, the development of root in cell-cell re-associations has been investigated as well (Honda et al., 2010; Hu et al., 2006a; Nait Lechguer et al., 2011).

Using embryonic dental cells, root formation could be initiated, but only after implantation of the cultured cell-cell re-associations (Fig. 3A, B; Hu et al., 2006a). In these conditions, the 
periodontium formed and elongated cells, similar to periodontal ligament fibers, extended from the root dentin to newly formed bone (Fig. 3C; Hu et al., 2006a). During the two weeks of implantation, the periodontium remained as a non-mineralized zone in between the dentin/cementum (Fig. 3D, E) and newly formed bone (Nait Lechguer et al., 2011). Longer periods of implantation will have to be tested in order to determine whether the absence of mineralization of this area can be preserved. The maintenance of homeostasis after long term implantation will also have to be investigated since the periodontal ligament is a rather complex tissue (for review see Nanci \& Bosshardt, 2006).

Attempts to regenerate the periodontium were also performed using postnatal stem cells from the periodontal ligament (Table 3; Seo et al., 2004). However, this potential cell source only represents a few cells. Other approaches have been developed, using bone marrow stem cells (Kawaguchi et al., 2004), or muscle derived-stem cells (Yang et al., 2010). The role of blood vessels and the participation of progenitor/pericytic cells in periodontium development and regeneration have been extensively reviewed (Ripamonti \& Petit, 2009). However, with these cells, the goal was very focused and no attempt was made to test how far, in a different context, they could give rise to other dental tissues. Such a hypothesis has been formulated recently (Rothova et al., 2011).

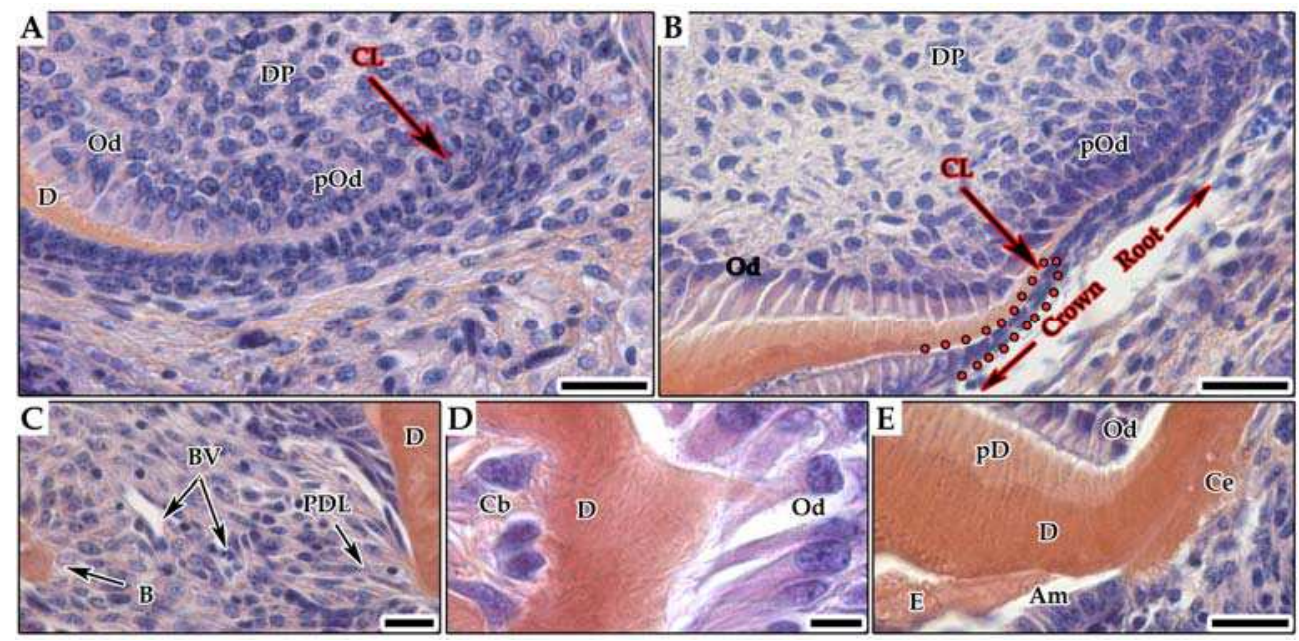

Fig. 3. Histology of root formation in cell-cell re-associations cultured for 8 days and implanted for 1 week (A) and 2 weeks under skin (B, C, D, E).

Between one week (A) and two weeks (B) of implantation, the root was forming.

Cementoblasts (D) secreted cementum (E) and the peridontium (C) remained as a nonmineralized zone in between the dentin/cementum and newly formed bone. Am: ameloblasts, B: bone, BV: blood vessel, Cb: cementoblasts, Ce: cementum, CL: cervical loop, D: dentin, DP: dental pulp, E: enamel Od: odontoblasts, pOd: preodontoblasts, pD: predentin, PDL: periodontal ligament. Bars $=10 \mu \mathrm{m},(\mathrm{D}) 20 \mu \mathrm{m}(\mathrm{C}, \mathrm{D})$ and $30 \mu \mathrm{m}(\mathrm{A}, \mathrm{B})$

\subsection{Organ vascularization}

The primary role of vascularization is related to oxygenation and metabolic exchanges, thus allowing cell survival. Since it cannot be functional in vitro, culturing large sized samples 
may be rapidly impaired, so that the implantation of the re-associations is absolutely necessary. The interstitial flow, generated by vascularization, may further mediate the extracellular transport of molecules, including growth factors, thus coupling mechanical and chemical signaling (Griffith \& Schwartz, 2006). The requirement of vascularization for dental matrices mineralization, explains its specific patterning in time and space during tooth development, including in the enamel organ (Fig. 4C; Manzke et al., 2005; Nait Lechguer et al., 2008). Cultured dental embryonic cell-cell re-associations could be vascularized after they were implanted under the skin or in the jaw of adult mice (Fig. 4A-E; Nait Lechguer et al., 2008, 2011; Nakao et al., 2007). It has been suggested that dental pulp stem cells might give rise to functional blood vessels (Cordeiro et al., 2008). However, cultured embryonic dental cell-cell re-associations from ICR mouse embryos have been implanted in GFP mice, which showed that all newly formed blood vessels entering the dental mesenchyme and the enamel organ, originated from the host (Nait Lechguer et al., 2008).
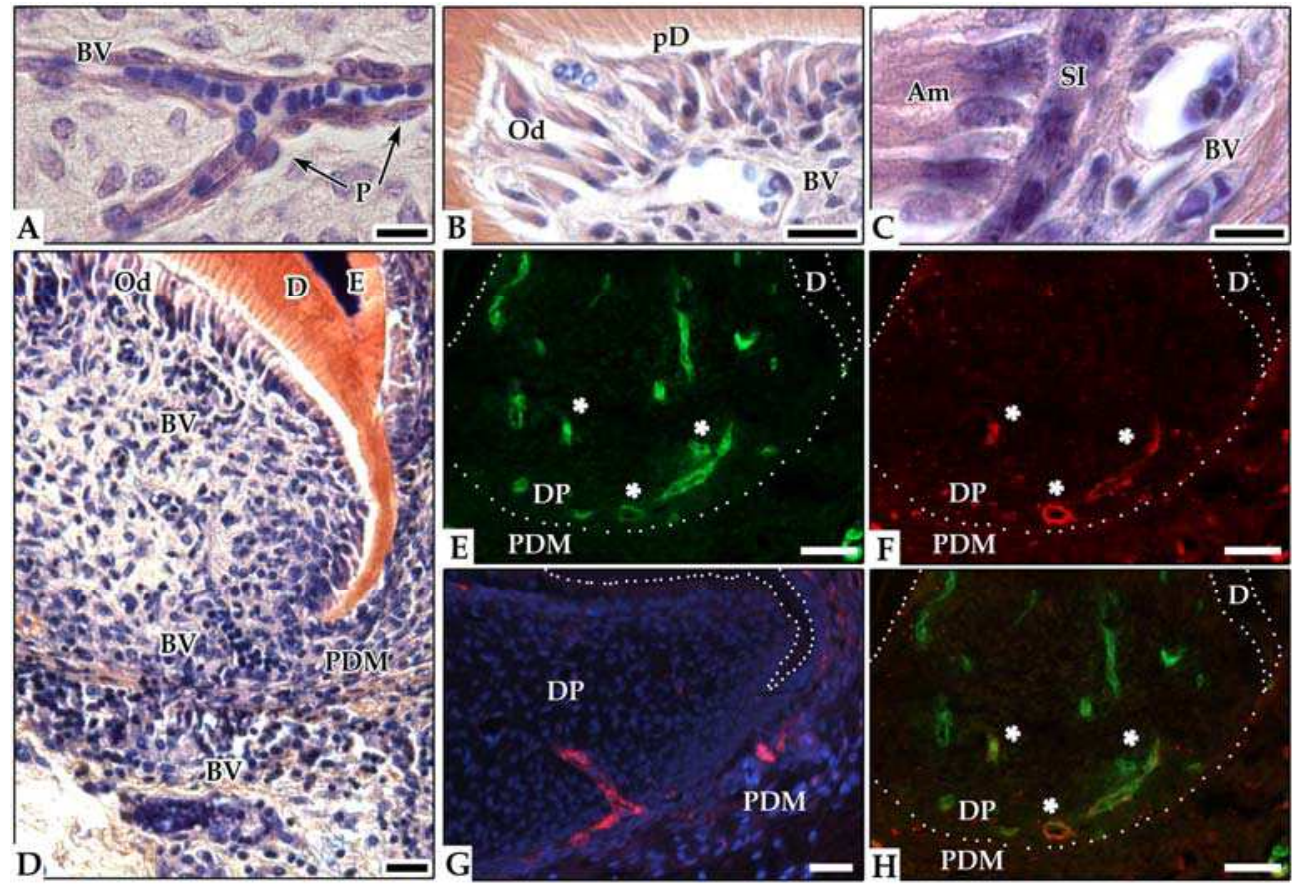

Fig. 4. Vascularization of subcutaneously implanted cultured epithelial/mesenchymal cellcell re-associations in adult ICR mice (A-H).

Epithelial/mesenchymal cell-cell re-associations were cultured for 8 days in vitro prior to implantation for 2 weeks under skin. Histology showed that blood vessels can enter in the dental pulp (D), migrate in the pulp (A), and reach odontoblasts (B). In the enamel organ, blood vessels were in close contact with the stratum intermedium $(\mathrm{C})$. Blood vessels were localized by immunofluorescent staining for CD31 (E, H) and pericytes were detected by immunofluorescence staining for $\alpha \mathrm{SMA}(\mathrm{G}, \mathrm{F}, \mathrm{H})$. Cells detected by $\alpha \mathrm{SMA}$ coming from the PDM could reach and enter in the pulp $(\mathrm{G})$. All blood vessels detected by CD31 were not positive for $\alpha \mathrm{SMA}(\mathrm{H})$. Implants were embedded in Tissue-Tek (Agar Scientific, Saclay, 
France) and frozen at $-30^{\circ} \mathrm{C}$. Immunostaining was performed on serial frozen sections $(7 \mu \mathrm{m})$ with rat monoclonal anti-mouse CD31 (1/100) (BD Pharmingen, Evry, France) and polyclonal rabbit anti-human $\alpha$ SMA (1/100) (Abcam, Cambridge, MA, USA). Sections were incubated for $2 \mathrm{hrs}$ at room temperature with the primary antibodies and for $1 \mathrm{hr}$ with donkey anti-rat secondary antibodies conjugated to Alexa $488(1 / 200)$ and chicken antirabbit conjugated to Alexa 594 (1/500) (Molecular Probes, Invitrogen SARL, Cergy Pontoise, France). Am: ameloblasts, BV: blood vessel, D: dentin, DP: dental pulp, E: enamel, Od: odontoblasts, P: pericyte, pD: predentin, PDM: periodontal mesenchyme, SI: stratum intermedium. Bars $=10 \mu \mathrm{m},(\mathrm{A}, \mathrm{C}) 20 \mu \mathrm{m}(\mathrm{B}, \mathrm{G})$ and $60 \mu \mathrm{m}(\mathrm{D}, \mathrm{E}, \mathrm{F}, \mathrm{H})$

Vascularization may play a further role, at least in the mesenchymal compartment. Cells with a mesodermal origin participate in the dental pulp formation including the blood vessels, which develop there (Chai et al., 2000; Rothova et al., 2011). Some of the mesenchymal stem cells present in the dental pulp might originate from perycites (Feng et al., 2010; Lovschall et al., 2007). Since the perivascular environment may play an essential role as it remains a potential source of stem cells possibly involved in reparative processes (Shi \& Gronthos, 2003), this context could explain the results published by Arany and coworkers (2009). These authors could obtain the formation of a tooth when re-associating a clonal cell line derived from a dental mesenchyme with a competent enamel organ and implanting these re-associations. As far as the implants can be vascularized, external cells might thus participate in the re-formation of the dental mesenchyme and allow restoring the complex cellular heterogeneity of this tissue, which hardly could be expected to originate from a clonal cell line (Keller et al., 2011). Pericytes in implanted cell-cell re-association were visualized after immunostaining for a smooth muscle actin ( $\alpha \mathrm{SMA})$ (Nehls \& Drenckhahn, 1991) and detected both in the apical part of the dental pulp (Fig. 4G) and peridental mesenchyme (Fig. 4F, H). All blood vessels detected by CD31 were not positive for $\alpha \mathrm{SMA}$ (Fig. $4 \mathrm{H}$ ). The presence of stem cells associated with the blood vessels during the early stages of vascularization of implanted cell-cell re-associations will have to be investigated to better understand the data from Arany et al. (2009).

\subsection{Innervation}

Besides the mediation of pain sensation, tooth innervation is involved in several complementary aspects such as the recruitment of immunocompetent cells (Byers et al., 2003; Fried et al., 2000), the control of odontoblast function (Fristad et al., 1999) and the prevention of tooth ankylosis. Being necessary for tooth functionality, the innervation remains as a major challenge in tooth engineering. The innervation of the tooth is initiated relatively late during development and involves sensory and sympathetic nerves. Complex molecular mechanisms regulate the timing and pattern of tooth innervation (Fried et al., 2007; Kettunen et al., 2005; Luukko et al., 2008). It has been suggested that the epithelium instructs and controls dental axons navigation in the dental mesenchyme (Luukko et al., 2008).

Attempts to implant extracted or engineered teeth in the jaw of adult mice could be achieved (Ferreira et al., 2007; Honda et al., 2006; Nait Lechguer et al., 2008; Nakao et al., 2007). However, it always remained quite far from nerves. Still a correct positioning of the implanted cell-cell re-associations in the jaw cannot be controlled in the mouse or rat, where they are relatively small. It is thus impossible to specifically position the prospective rootforming part of the implant so that it is oriented towards the alveolar nerve (Honda et al., 2006; Nait Lechguer et al., 2008). In parallel, preliminary experiments have been performed 
to test the possibility to obtain the innervation of cultured cell-cell re-associations after implantation under the skin. For this purpose, embryonic dental cell-cell re-associations were implanted together with DRG (Fig. 5A). After 2 weeks of implantation, immunostaining for peripherin showed the axonal growth in the peridental tissues (Fig. 5C, D), but not in the dental mesenchyme (Fig. 5B, C, D). The impossibility to innervate the dental mesenchyme might be related to the embryonic stage (ED14) that was used to prepare dental cells. Indeed at ED14, innervation remains inhibited in physiological conditions, and only becomes possible postnatally (Luukko et al., 2008). The expression of semaphorins, which regulate innervation, will have to be investigated in implanted cell-cell re-associations.

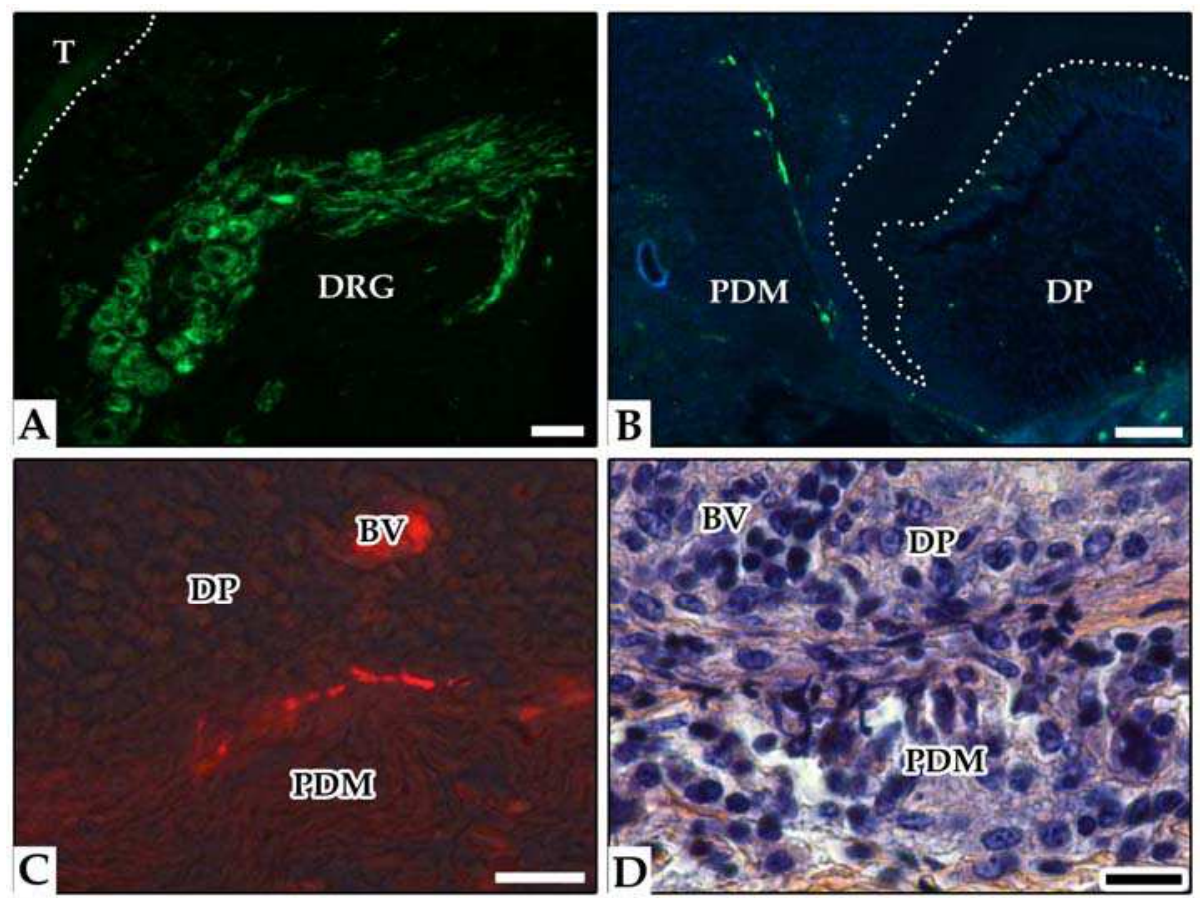

Fig. 5. Innervation of subcutaneously implanted cultured epithelial/mesenchymal cell reassociations with DRG in adult ICR mice (A-D).

Epithelial-mesenchymal cell-cell re-associations were cultured for 8 days in vitro prior to coimplantation with DRG from ED12. After 2 weeks of implantation under the skin (A), axons and DRG were detected by immunofluorescent staining for peripherin. Axons growing from DRG in contact with the PDM (A, B) were detected at the limit between PDM and DP (C, D). However, they never entered the DP (B, C). Implants were fixed with $4 \%$ paraformaldehyde and embedded in paraffin. Immunostaining was performed on serial paraffin sections $(7$ $\mu \mathrm{m})$ with rabbit polyclonal anti-human peripherin (1/100) (Abcam, Cambridge, MA, USA). Sections were incubated for $2 \mathrm{hrs}$ at room temperature with the primary antibody and for $1 \mathrm{hr}$ with chicken anti-rabbit conjugated to Alexa 594 (1/500) and to Alexa $488(1 / 200)$ (Molecular Probes, Invitrogen SARL, Cergy Pontoise, France). BV: blood vessel, DP: dental pulp, DRG: dorsal root ganglia, PDM: periodontal mesenchyme, T: tooth. Bars $=20 \mu \mathrm{m}(\mathrm{C}$, D) and $40 \mu \mathrm{m}(\mathrm{A}, \mathrm{B})$ 


\section{Using matrix or artificial polymers instead of cells only}

A tricky point in the experimental designs being developed in different laboratories is whether to use scaffolds or not. Several scaffolds with different composition and complementary purposes have been used for tooth engineering (Fig. 6).

\subsection{Pre-shaped scaffolds}

In some instances, scaffolds of different natures have been designed to try to "pre-shape" the tooth to be engineered (Fig. 6; Kim et al., 2010; Young et al., 2005). Despite their potential interest to direct crown morphology, scaffolds also have their own limitations. Indeed, they may impair correct cell-cell interactions, and thus interfere both with the general histogenesis and with epithelial-mesenchymal interactions. This is critical since these interactions control all aspects of tooth development: epithelial histogenesis, crown morphogenesis, and cell differentiation, as well as root development (Jernvall \& Thesleff, 2000; Ruch et al., 1982; Slavkin et al., 1984).

The question of tissue interfaces junction has been raised with other models such as the complex ligament-, tendon- or cartilage-bone interfaces. For this specific purpose, attempts are made to develop stratified scaffolds (Lu et al., 2010). Similar challenges exist when trying to restore dentin/enamel, dentin/cementum, or cementum/periodontal fibers interfaces and maintain their specific mechanical properties. During tooth development, tissues interfaces usually show multi-step formation where extensive matrix remodeling takes place (Bosshardt et al., 2005; Ho et al., 2009; Imbeni et al., 2005). In all these interfaces, there is a tight structure-function relationship. In case of multiple bone interfaces, these characteristics were taken into account to design biomimetic stratified scaffolds (Lu et al., 2010). In this specific case however, scaffolds were not designed to try shaping a tissue, but to set up a 3D spatial organization of cells activities. The ultimate goal was to reproduce physiological mechanical properties by patterning matrix heterogeneity. Similarly for periodontium engineering, attempts have been made to design hybrid scaffolds allowing the maintenance of the ligamentous fibers spatial organization (Park et al., 2010). According to these authors, the design will have to be further developed by introducing mechanical forces in order to better adjust the spatial organization of fibers.

Depending on their structure and surface organization, scaffolds may also interfere with horizontal signaling within the odontoblast and/or ameloblast layer(s). The main problem would be related to the odontoblast layer, since the extent of the gradients which they may form will have direct consequences on the patterning of ameloblast differentiation and, ultimately, on enamel organization (Nait Lechguer et al., 2011). The morphology of the epithelial-mesenchymal junction, just before ameloblast differentiate, is thought to represent the physiological scaffold and template for the final crown shape (Skinner \& Gunz, 2010). During tooth development, the different cusps show different specific kinetics of cell differentiation (Lisi et al., 2003). Still very little is known about the mechanisms involved in it despite active research to address this question (SalazarCiudad \& Jernvall, 2004, 2010).

Obviously, the design of a scaffold is strongly related to the tissue to be engineered (Chan \& Leong, 2008) and to the purpose of its use: either for organ shaping (Kim et al., 2010; Young et al., 2005), or, more simply to maintain high cell density and cohesion as discussed below (Arany et al., 2009; Nakao et al., 2007). 


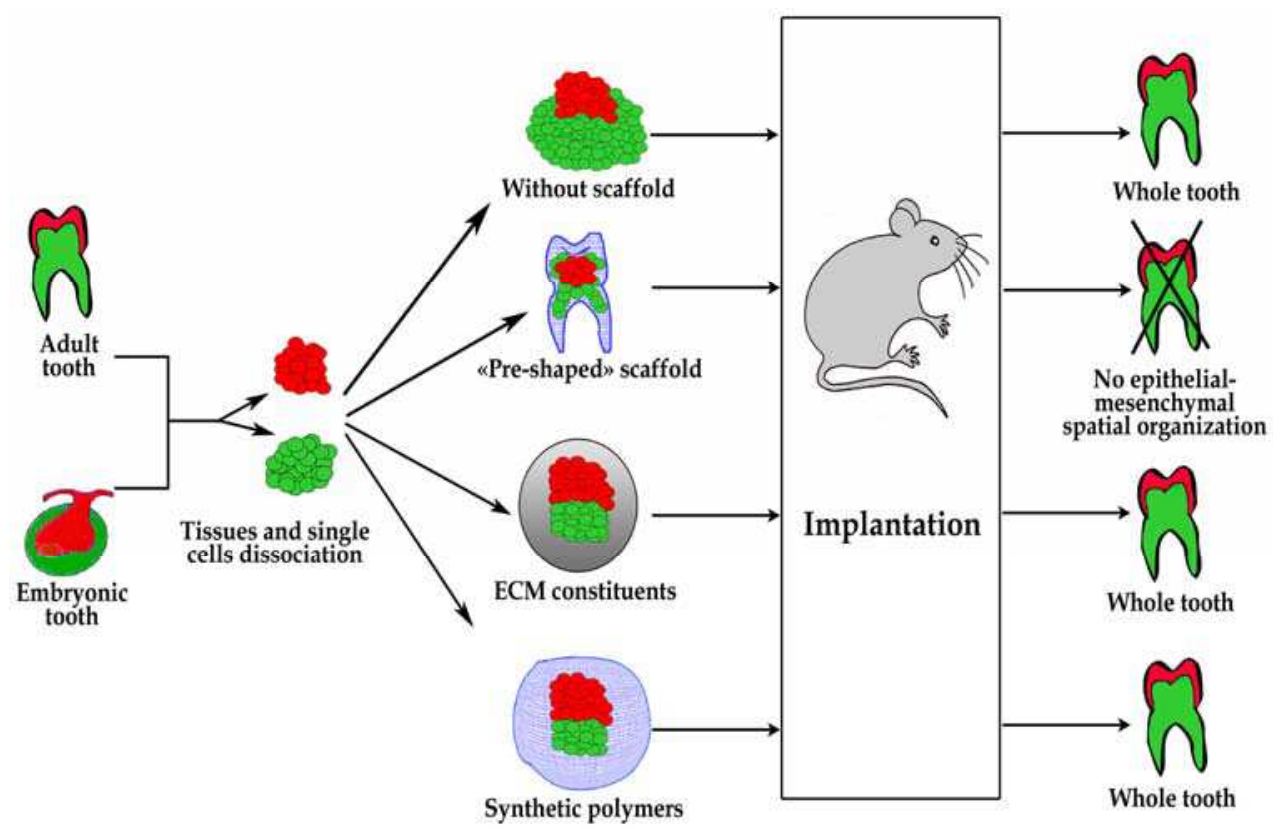

Fig. 6. Schematic representation of experimental procedures developed for tooth organ engineering

\subsection{Extracellular matrix constituents}

For tooth engineering, extracellular matrix (ECM) constituents (Fig. 6) were not used to shape the forming organ but either to maintain cells together and work with high cell density or to retain signaling molecules involved in stimulating morphogenesis and/or cell differentiation (Griffith \& Schwartz, 2006; Honda et al., 2005; Huang et al., 2010; Nakao et al., 2007; Sumita et al., 2009). The level of signaling in the mesenchyme was recognized as a potentially limiting factor in tooth engineering (Hu et al., 2006a; Nait Lechguer et al., 2009). The matrix may be involved in signaling either directly through cell surface receptors, or indirectly because of its ability to differentially bind diffusible growth factors, and also because it contains enzymes modulating or tuning the two other ways (Discher et al., 2009; Reilly \& Engler, 2010; Rhodes \& Simons, 2007). These different molecules may explain why and how the ECM can interfere with distinct cellular activities such as the adhesion, migration, proliferation, survival and differentiation. For this reason also, it is difficult to design the composition of the ECM scaffold. Beside matrix stiffness, which may interfere with cell migration and thus with morphogenesis, Griffith and Schwartz (2006) took into account the formation of molecular gradients, one parameter, which may be very important for tooth formation. The main difficulty in using ECM constituents is related to the physiological complexity of the 3D environment, as it exists in a tissue. However, cells can rapidly modify and re-adjust this environment as far as ECM constituents can initially be populated by the different cell types present in a tissue, so that a physiological homeostasis and histogenesis can then be restored (Keller et al., 2011). ECM scaffold remodeling is thus an important parameter to be investigated when the organ formation progresses (Badylak et al., 2009). 
Different matrix constituents have been used for tooth engineering (Table 1). However, collagen, under different forms, was by far the most frequently used (Honda et al., 2007; Nakao et al., 2007; Sumita et al., 2006). Collagen gel has been successfully used for dental cells encapsulation, as obviously neither interfering with the epithelial histogenesis nor with the patterning of cell differentiation (Arany et al., 2009; Honda et al., 2008; Nakao et al., 2007). It would be interesting to analyze the behavior of epithelial cells in such an environment, which they physiologically never meet.

Comparing the potentialities of different scaffolds, possible inhibitory effects of collagen on hard tissue formation have been reported (Ohara et al., 2010). However, other studies ended up with tooth formation (Arany et al., 2009; Nakao et al., 2007). Although their degree of mineralization was not measured, dentin and enamel were secreted in these two independent studies.

\begin{tabular}{|c|c|c|}
\hline \multicolumn{3}{|c|}{ ECM constituents } \\
\hline \multirow[t]{2}{*}{ Collagen gel } & Whole tooth & $\begin{array}{l}\text { Komine et al., } 2007 \\
\text { Nakao et al., } 2007 \\
\text { Arany et al., } 2009\end{array}$ \\
\hline & Dentin and enamel-like structures & Ohara et al., 2010 \\
\hline Collagen sponge & Whole tooth & Sumita et al., 2006 \\
\hline Fibrin gel & Dentin and enamel-like structures & Ohara et al., 2010 \\
\hline GCHT & Whole tooth & Kuo et al., 2011 \\
\hline
\end{tabular}

Table 1. Extracellular matrix constituents used for tooth engineering

\subsection{Synthetic polymers}

Several synthetic polymers have been used to embed cells for tooth engineering (Fig. 6), mostly polyglycolic acid (PGA) and poly-lactideco-glycolide (PLGA) (Table 2). They were chosen for the possibility they offer to control their structural and mechanical properties (Hacking \& Khademhosseini, 2009). For this reason, they have been widely used for tissue engineering. The possibility to re-create a specific histological organization has been investigated, in the case of lung tissue engineering by growing pluripotent cells seeded onto synthetic polymers, showing that identifiable pulmonary structures could develop (Cortiella et al., 2006). Although PGA is satisfactory to grow cells in vitro, this polymer can induce inflammatory reactions after implantation in immunocompetent hosts (Ceonzo et al., 2006; Cortiella et al., 2006).

Different groups have used PGA for tooth engineering (Duailibi et al., 2004, 2008; Iwatsuki et al., 2006; Ohara et al., 2010), but the risk of inflammation was only discussed by Duailibi et al. (2008). Concerning biodegradation, PGA fiber meshes were still present after 10 days 
of implantation (Iwatsuki et al., 2006). It will be important to more precisely evaluate what happens at later stages.

As stated above, synthetic polymers might introduce discontinuities in the setting of gradients of cell progression towards differentiation and thus interfere with the geometry of epithelial-mesenchymal interactions. However, Honda et al., (2008) showed convincing images of tooth formation using dental cells seeded in PGA polymers, but coated with collagen.

A comparative study suggested that the potential of PGA scaffold to support tooth formation was not as good as collagen sponges scaffold (Honda et al., 2010). Considering the initial stages of tooth formation, similar conclusions were drawn when comparing collagen or fibrin gels with PGA or ß-tricalcium phosphate (B-TCP) (Ohara et al., 2010).

\section{Synthetic polymers}

\begin{tabular}{|c|c|c|}
\hline PGA (Polyglycolate) & $\begin{array}{l}\text { Enamel, dentin and pulp tissue } \\
\text { Enamel-like structure and dentin }\end{array}$ & $\begin{array}{l}\text { Duailibi et al., } 2004 \\
\text { Ohara et al., } 2010\end{array}$ \\
\hline \multirow{2}{*}{ Collagen coated PGA } & Ameloblast and dentin tissue & Honda et al., 2005 \\
\hline & Whole tooth & $\begin{array}{l}\text { Iwatsuki et al., } 2006 \\
\text { Honda et al., } 2008\end{array}$ \\
\hline \multirow{2}{*}{ PLGA (poly-L-lactate-co-glycolate) } & Enamel, dentin and pulp tissue & Duailibi et al., 2004 \\
\hline & Enamel-and dentin-like tissue & Duailibi et al., 2008 \\
\hline PLLA (poly-L-lactate) & $\begin{array}{l}\text { Functional odontoblasts and } \\
\text { tubular dentin }\end{array}$ & Sakai et al., 2010 \\
\hline NF-PLLA (nanofibrous - poly-L-lactic acid) & Odontoblast-like cells & Wang et al., 2010 \\
\hline PGA/PLLA (Polyglycolate/poly-L-lactate) & Enamel-and dentin-like tissue & Duailibi et al., 2008 \\
\hline \multicolumn{3}{|l|}{ Inorganic scaffolds } \\
\hline$\beta$-TCP ( $\beta$-tricalcium phosphate) & Odontoblast- like cells & Ohara et al., 2010 \\
\hline $\begin{array}{l}\text { HA/TCP (hydroxyapatite/tricalcium } \\
\text { phosphate) }\end{array}$ & $\begin{array}{l}\text { Dentin-like matrix and odontoblast } \\
\text {-like cells }\end{array}$ & $\begin{array}{l}\text { Gronthos et al., } 2000 \\
\text { Miura et al., } 2003 \\
\text { Sonoyama et al., } 2006\end{array}$ \\
\hline
\end{tabular}

Table 2. Synthetic polymers and inorganic scaffolds used for tooth engineering 


\section{Cell sources}

Although embryonic cells represent an excellent tool to set up methodologies for tooth engineering, they are not a cell source to be used in a clinical context. One possible alternative would be the use of the stem cells evidenced in numerous adult organs (Bergmann \& Steller, 2010). To engineer a complete tooth and be able to reproduce the epithelial-mesenchymal interactions taking place during development, it will be necessary to combine mesenchymal and epithelial adult stem cells with odontogenic potentialities. The identification and selection of these two cell populations/sources is a major challenge.

For the mesenchymal compartment, the use of mesenchymal stem cells (MSCs) certainly appears as first evidence. These cells were initially characterized in the bone marrow (Friedenstein et al., 1970; Pittenger et al., 1999). They appear as a subset of fibroblast-like cells able to form colonies that can be selected by their adherence to plastic and expanded in vitro. As classical stem cells, they are capable of self-renewal and of displaying multilineage differentiation ability in vitro, not only towards the classical "triumvirate", osteoblasts, adipocytes and chondrocytes, but also towards the endothelial, cardiomyocytes or neural fate depending on in vitro induction (for review see Nombela-Arrieta et al., 2011). This multipotentiality together with their easiness of in vitro expansion has made these cells promising in regenerative medicine, mainly dealing with bone defects, cardiac repair, and MSCs immunosuppressive properties (for review see Augello et al., 2010; Chanda et al., 2010). Bone marrow stem cells (BMSCs) have also been tested for tooth enginering (Hu et al., 2006b; Nait Lechguer et al., 2009; Ohazama et al., 2004). They could substitute the dental mesenchyme, and engage in tooth formation (Ohazama et al., 2004). Furthermore, they could also be reprogrammed in situ to engage in ameloblast functional differentiation (Hu et al., 2006b).

Since their first description, MSC-like cells have been reported in many embryonic and adult connective tissues (da Silva Meirelles et al., 2006), including some of the adult tooth: dental pulp of permanent (Gronthos et al., 2000) or deciduous teeth (Miura et al., 2003), periodontal ligament (Seo et al., 2004), apical papilla (Sonoyama et al., 2008) or dental follicle (Casagrande et al., 2011; Morsczeck et al., 2005). Among dental MSC-like cells, the dental pulp stem cells (DPSCs) are the most easily accessible. They have already demonstrated their plasticity and capacity to participate in tissue repair (for review see Huang, 2009). DPSCs have been described in human (Gronthos et al., 2000; Miura et al., 2003; Sonoyama et al., 2008), rat (Yang et al., 2007) and mouse (Balic et al., 2010). Most dental mesenchymal cells are believed to derive from the cranial neural crest (Chai et al., 2000; Lumsden, 1984), DPSCs appear as candidates of choice to substitute the mesenchymal component of the tooth. Moreover, they might have retained some type of "memory" of their tissue of origin and preferentially differentiate towards an odontogenic program (Batouli et al., 2003; Gronthos et al., 2000 and Fig. 4 therein).

The stem cells of the dental pulp (Table 3, SHEDs, DPSCs or SCAPs) constitute per se an heterogenous cell population which, depending on the isolation, selection and culture procedures may display different features and degrees of stemness (Table 3, Bakopoulou et al., 2011; Huang et al., 2006). It is remarkable that although the majority of studies involved cells isolated by enzymatic dissociation of the pulpal tissue, the most immature dental pulp stem cells were obtained from explants culture (Siqueira da Fonseca et al., 2009). 
Determining which type of DPSCs is the best suited for tooth engineering is therefore an essential question. The purification of a homogeneous DPSCs population is not possible due to a lack of known specific markers. Pulp stem cells are thus enriched on their ability to form colonies (Gronthos et al., 2000), their expression of cell surface molecules such as STRO-1 (Gronthos et al., 2000), or CD34 (Laino et al., 2006) or on their capacity of exclusion of a DNA binding dye (Iohara et al., 2006). Not surprisingly, the resulting different cell populations display various differentiation potentials, upon appropriate in vitro induction (for review see Huang, 2009) and are able to participate in bone (d'Aquino et al., 2009; Seo et al., 2008), neuronal (Arthur et al., 2008) and corneal tissue formation in vivo (Table 3; Gomes et al., 2010). In an implanted tooth slice model, heterogeneous populations of DPSCs, SCAPs or SHEDs have already shown their capacity to participate in the formation of a pulp-like tissue with dentin secretion and apposition (Huang et al., 2010; Sakai et al., 2010). However, the potential of these different populations to participate in whole tooth formation has not yet been investigated. For this purpose, it will be necessary to set up models for preclinical evaluations and to standardize the procedures. A major drawback in this field lies in the fact that most of these pulp stem cell sub-populations are described in the human tooth, while experimental strategies to test their competence to participate in tooth formation have been set up with murine models (Arany et al., 2009; Hu et al., 2006a; Nakao et al., 2007; Ohazama et al., 2004).

A hint that post-natal dental pulp cells may maintain such a potential, at least to a certain extent, comes from the work of Masaki Honda and coworkers. These authors have shown that unselected epithelial and mesenchymal cells derived from porcine third molar (6 months after birth), are able to participate in the formation of a tooth-like tissue (Honda et al., 2008). The precise nature of these cells and their possible relationship with dental pulp stem cells will have to be investigated. It will also have to be determined why, in these experimental conditions, tooth formation was not impaired by mechanisms of cell sorting out (Manning et al., 2010; Steinberg, 1962, 1963).

Tooth engineering also requires epithelial stem cells. Dental epithelial stem cells have been described in the continuously growing mouse incisor, which is a very peculiar tooth (Harada et al., 1999). However, all epithelial cells have disappeared in the erupted molar, except for the very restricted population of Malassez rests, when it exists (Huang et al., 2009; Shinmura et al., 2008). Therefore, the search for non-dental epithelial cell sources is ongoing.

The palatal mucosal epithelium isolated from embryos or newborn mice has been shown to be able to substitute for a dental epithelium, and to contribute to tooth formation in a reassociation model using embryonic dental mesenchyme. Cultured dissociated palatal epithelial cells can maintain this potential up to one month post-natally, provided they are cultivated as cell sheets to maintain epithelial cell properties (Nakagawa et al., 2009).

Along the same line, young human skin keratinocyte progenitors, cultured in cell sheets, can contribute to tooth-crown like structure formation after chimeric re-association with ED 13.5 mouse molar mesenchyme (Wang et al., 2010). However, in these conditions, ameloblasts do not differentiate. Their differentiation needed to be induced by exogenous FGF8 (Wang et al., 2010).

In the ongoing search for cell sources, an interesting alternative resides in the induced pluripotent stem cells (iPSCs). Since the pioneer work of Takahashi and Yamanaka (2006), it 
has been demonstrated that mouse adult somatic cells can be reprogrammed to an embryonic-like state, by the introduction of 4 transcription factors, Oct4, Sox2, c-Myc and Klf4 or Lin28. These cells exhibit the morphology and growth properties of murine embryonic stem cells and appear capable of contributing to virtually every cell type in the body (Maherali et al., 2007). Their human counterparts have subsequently been generated (Lowry et al., 2008; Takahashi et al., 2007). Emerging data suggest that iPSCs retain a memory of their tissue of origin (Quatrocelli et al., 2011; Tian et al., 2011) and therefore could differentiate more easily towards their original program (Hu et al., 2010). Human iPSCs have already been generated from dental pulp stem cells (SHEDs, DPSCs and SCAPs) (Duan et al., 2011; Tamaoki et al., 2010) and different types of epithelia (Buchholtz et al., 2009; Novak et al., 2010). The potential of such cells will have to be evaluated when grown in re-association, to determine whether they are indeed valuable candidates for whole tooth engineering.

Whatever the chosen cells, further studies to improve the success rate in tooth formation should focus primarily on the enrichment/purification, of competent cells. This will require the finding of markers permitting this enrichment as well as specific culture protocols allowing their expansion and the maintenance of their differentiation potentials in vitro.

\section{Maintenance of cell potentialities in vitro}

Adult stem cells are known to reside in defined anatomical compartments specified by cellular and acellular components. This specialized microenvironment is known as a niche and was first described as a concept in the context of hematopoiesis (Schofield, 1978). The existence of niches has then been validated in many other tissues (Weissman, 2000). It integrates systemic and local cues (growth factors, ECM as well as specific cell types) to maintain a balance between self-renewal and differentiation. In the absence of stimuli, adult stem cells remain quiescent but signals generated by inflammation, infection or lesion will lead to their recruitment/activation towards differentiation and repair.

In contrast to the niche of the intestine, hair or blood stem cells whose understanding has progressed over the recent years (for review see Fuchs \& Segre, 2000 and Li \& Clevers, 2010 and references therein), the dental pulp stem cell niche is still poorly understood. This might be explained by the facts that 1) the pulp is not an actively renewing tissue, 2) there is a lack of specific markers identifying its stem cells and 3) it is technically difficult to work with strongly mineralized tissue. DPSCs are thus essentially defined by their functionalities. DPSCs freshly established in culture, present a phenotype similar to BMSCs (Shi et al., 2001). They express STRO-1 and a series of surface markers, proposed by the International Society for Cell Therapy for the identification of human MSCs (Dominici et al., 2006). However the extent to which these markers reflect the in vivo phenotype remains an unresolved question. In normal pulp, the STRO-1 expressing cells are only found in the microvasculature (Shi \& Gronthos, 2003), an observation compatible with the hypothesis that DPSCs, as MSCs from other tissues, might correspond to pericytes (Crisan et al., 2008; Feng et al., 2010). Indirect data from BrdU labeling experiments have brought support to this hypothesis (Ishikawa et al., 2010; Téclès et al., 2005). But the fact that DPSCs appear as a heterogeneous cell population raises the question of the existence of other potential stem cell niches in the pulp (Harichane et al., 2011; Mitsiadis et al., 1999, 2003). 
Tooth Organ Engineering:

\begin{tabular}{|c|c|c|c|c|}
\hline Name & $\begin{array}{l}\text { Isolation and } \\
\text { selection }\end{array}$ & $\begin{array}{c}\text { In vitro } \\
\text { differentiation } \\
\text { potential }\end{array}$ & $\begin{array}{c}\text { Invivo } \\
\text { differentiation } \\
\text { potential }\end{array}$ & $\begin{array}{c}\text { First } \\
\text { description }\end{array}$ \\
\hline DPSCs & $\begin{array}{l}\text { Enzymatic dissociation } \\
\text { Stro1+ or Colony- } \\
\text { forming units/low } \\
\text { density inoculation }\end{array}$ & $\begin{array}{l}\text { Odontoblasts } \\
\text { Osteoblasts } \\
\text { Adipocytes } \\
\text { Neurons }\end{array}$ & $\begin{array}{l}\text { Bone-like tissue } \\
\text { Dentin-pulp like } \\
\text { complex }\end{array}$ & Gronthos et al., 2000 \\
\hline SBP/DPSCs & $\begin{array}{l}\text { Enzymatic dissociation } \\
\text { CD34+ }\end{array}$ & $\begin{array}{l}\text { Osteoblasts } \\
\text { Endotheliocytes } \\
\text { Melanocytes }\end{array}$ & $\begin{array}{l}\text { Bone-like tissue } \\
\text { Alveolar bone }\end{array}$ & Laino et al., 2006 \\
\hline SPCs & $\begin{array}{l}\text { Enzymatic dissociation } \\
\text { Hoecht exclusion }\end{array}$ & $\begin{array}{l}\text { Odontoblasts } \\
\text { Chondrocytes } \\
\text { Adipocytes } \\
\text { Neurons }\end{array}$ & $\begin{array}{l}\text { Odonto/osteodentinobla } \\
\text { sts } \\
\text { Pulp regeneration }\end{array}$ & Iohara et al., 2006 \\
\hline iDPSCs & $\begin{array}{l}\text { Outgrowth culture } \\
\text { Low density inoculation }\end{array}$ & $\begin{array}{l}\text { Odontoblasts } \\
\text { Corneal epithelial } \\
\text { cells } \\
\text { Muscle cells } \\
\text { Osteoblasts } \\
\text { Neurons } \\
\text { Chondrocytes }\end{array}$ & $\begin{array}{l}\text { Contribution to preterm } \\
\text { chimera and to corneal } \\
\text { reconstruction }\end{array}$ & Kerkis et al., 2006 \\
\hline SHEDs & $\begin{array}{l}\text { Enzymatic dissociation } \\
\text { Colony-forming } \\
\text { units/low density } \\
\text { inoculation }\end{array}$ & $\begin{array}{l}\text { Odontoblasts } \\
\text { Osteoblasts } \\
\text { Muscle cells } \\
\text { Adipocytes } \\
\text { Neurons } \\
\text { Endotheliocytes }\end{array}$ & $\begin{array}{l}\text { Dentin-pulp tissue } \\
\text { Odontoblast-like cells } \\
\text { Bone }\end{array}$ & Miura et al., 2003 \\
\hline PDLScs & $\begin{array}{l}\text { Enzymatic dissociation } \\
\text { Low density inoculation }\end{array}$ & $\begin{array}{l}\text { Cementoblasts } \\
\text { Osteoblasts } \\
\text { Adipocytes } \\
\text { Chondrocytes } \\
\text { Neurons } \\
\end{array}$ & $\begin{array}{l}\text { Cementum-like } \\
\text { formation } \\
\text { PDL-like formation }\end{array}$ & Seo et al., 2004 \\
\hline DFPCs & $\begin{array}{l}\text { Enzymatic dissociation } \\
\text { Low density inoculation }\end{array}$ & $\begin{array}{l}\text { Cementoblasts } \\
\text { Osteoblasts } \\
\text { Odontoblasts } \\
\text { Adipocytes } \\
\text { Muscle cells } \\
\text { Chondrocytes } \\
\text { Neurons }\end{array}$ & $\begin{array}{l}\text { PDL-like formation } \\
\text { Cementum matrix }\end{array}$ & Morsczeck et al., 2005 \\
\hline SCAPs & $\begin{array}{l}\text { Enzymatic dissociation } \\
\text { Low density inoculation }\end{array}$ & $\begin{array}{l}\text { Odontoblasts } \\
\text { Adipocytes } \\
\text { Muscle cells } \\
\text { Chondrocytes } \\
\text { Neurons }\end{array}$ & $\begin{array}{l}\text { Dentin-pulp like } \\
\text { complex } \\
\text { Odontoblasts }\end{array}$ & Sonoyama et al., 2008 \\
\hline
\end{tabular}

Table 3. Different types of stem cells from the tooth: isolation, culture procedures and differentiation potentials

Working with stem cells requires their growth and expansion in vitro. However, it is well known that in vitro culture conditions go along with major changes in gene expression. For instance, culture on specific substrates, in different media, serum substitutes, oxygen 
concentration has been shown to deeply affect the transcriptome/epigenome of ES cells (Allegrucci et al., 2007; Forsyth et al., 2008). Recent studies have further shown that changes in culture conditions may modify the potency of stem cells or reprogram adult stem cells to endow them with a broader differentiation potential (for review see Roobrouck et al., 2011). Similarly, cultured DPSCs have been shown to undergo phenotypic changes, losing markers while acquiring others with subculture (Govindasamy et al., 2010; Patel et al., 2009; Yu et al., 2010). Trying to improve the culture conditions of DPSCs for their use in whole tooth engineering is now a major challenge.

\section{Conclusion and prospects}

Recent studies in tooth engineering led to the analysis of different potential cell sources and to the development of several complementary experimental approaches. The biological constraints, which become better characterized as research progresses, will necessarily restrict the number of protocols and strategies.

Potential human cell sources have been reported (Gronthos et al., 2000; Miura et al., 2003), while banks for autologous cell sources are being developed (Arora et al., 2009; Tamaoki et al., 2010; Woods et al., 2009). The biological potentialities of the different cells types, which recently were identified from human sources, will have to be tested both in vitro and in vivo. This will allow determining whether they may recapitulate the different developmental stages and lead to the engineering of a functional tooth. The next challenge will be to deal with the engineering of larger teeth, where full vascularization and innervation will become critical.

As far as possible, it may be better to work in the absence of scaffold or matrices to engineer whole teeth (Hu et al., 2005, 2006a; Ohazama et al., 2004). It better fits with the necessity to preserve epithelial-mesenchymal interactions and with the maintenance of gradual cell differentiation. Furthermore, it is important to prevent any risk of delayed immune response, which may occur with collagen (Zippel et al., 2008) or PLGA scaffolds (Tavassol et al., 2010). As a broad question, related to tissue engineering and regeneration in general, the possible negative consequences of using collagen, PGA and other components to embed cells are investigated (Marx et al., 2008; Ohara et al., 2010; Pihlajamäki et al., 2010). Scaffolds made of PGA fibers were used to tooth bud cells from 6 month old miniature pig third molars (Ohara et al., 2010). PGA supported odontoblast-like cell functional differentiation, but these conditions did not seem to be optimal for histogenesis. PGA was also used by the same group to grow embryonic dental cells from molars at ED14 (Iwatsuki et al., 2006). In these conditions, after implantation, teeth formed, which showed all aspects of epithelial histogenesis and gradients of functional odontoblasts and ameloblasts (Iwatsuki et al., 2006). However, the same results could be obtained without scaffold (Nait Lechguer et al., 2008, 2011).

All together, these results indicate that the limitations in tooth engineering are more related to the cell sources and to the difficulty to maintain their potentialities during cell expansion in vitro.

\section{Acknowledgements}

The authors thank Hervé Gegout for the histology. This work was funded by the Dental School from Strasbourg University, by the IFRO, by a grant from Fondation des Gueules 
Cassées and by a grant supporting Strategic Research of Nihon University, School of Dentistry at Matsudo from MEXT, 2008-2012.

\section{References}

Allegrucci, C.; Wu, Y.Z.; Thurston, A.; Denning, C.N.; Priddle, H.; Mummery, C.L.; Wardvan Oostwaard, D.; Andrews, P.W.; Stojkovic, M.; Smith, N.; Parkin, T.; Jones, M.E.; Warren, G.; Yu, L.; Brena, R.M.; Plass, C. \& Young, L.E. (2007). Restriction landmark genome scanning identifies culture-induced DNA methylation instability in the human embryonic stem cell epigenome. Hum. Mol. Genet. Vol.16, No.10, (May 2007), pp. 1253-1268, ISSN 1460-2083

Arany, S.; Kawagoe, M. \& Sugiyama, T. (2009). Application of spontaneously immortalized odontoblast cells in tooth regeneration. Biochem. Biophys. Res. Commun. Vol.381, No.1, (March 2009), pp. 84-89, ISSN 0006-291X

Arora, V.; Arora, P. \& Munshi, A.K. (2009). Banking stem cells from human exfoliated deciduous teeth (SHED): saving for the future. J. Clin. Pediatr. Dent. Vol.33, No.4, (Summer 2009), pp. 289-294, ISSN 1053-4628

Arthur, A.; Rychkov, G.; Shi, S.; Koblar, S.A. \& Gronthos, S. (2008). Adult human dental pulp stem cells differentiate toward functionally active neurons under appropriate environmental cues. Stem Cells Vol.26, No.7, (July 2008), pp.1787-1795, ISSN 15494918

Augello, A.; Kurth, T.B. \& De Bari, C. (2010). Mesenchymal stem cells: a perspective from in vitro cultures to in vivo migration and niches. Eur. Cell Mater. Vol.1, No.20, (September 2010), pp.121-133, ISSN 1473-2262

Badylak, S.F.; Freytes, D.O. \& Gilbert, T.W. (2009). Extracellular matrix as a biological scaffold material: Structure and function. Acta Biomater. Vol.5, No.1, (January 2009), pp. 1-13, ISSN 1742-7061

Bakopoulou, A.; Leyhausen, G.; Volk, J.; Tsiftsoglou, A.; Garefis, P.; Koidis, P. \& Geurtsen, W. (2011). Assessment of the impact of two different isolation methods on the osteo/odontogenic differentiation potential of human dental stem cells derived from deciduous teeth. Calcif. Tissue Int. Vol.88, No.2, (February 2011), pp.130-141, ISSN 1432-0827

Balic, A.; Aguila, H.L.; Caimano, M.J.; Francone, V.P. \& Mina, M. (2010). Characterization of stem and progenitor cells in the dental pulp of erupted and unerupted murine molars. Bone Vol.46, No.6, (June 2010), pp.1639-1651, ISSN 8756-3282

Batouli, S.; Miura, M.; Brahim, J.; Tsutsui, T.W.; Fisher, L.W.; Gronthos, S.; Robey, P.G. \& Shi, S. (2003). Comparison of stem-cell-mediated osteogenesis and dentinogenesis. J. Dent. Res. Vol.82, No.12, (December 2003), pp. 976-981, ISSN 1544-0591

Bergmann, A. \& Steller, H. (2010). Apoptosis, stem cells, and tissue regeneration. Sci. Signal. Vol.26, No.145, (October 2010), pp.re8, ISSN 1937-9145

Bosshardt, D.D.; Degen, T. \& Lang, N.P. (2005). Sequence of protein expression of bone sialoprotein and osteopontin at the developing interface between repair cementum and dentin in human deciduous teeth. Cell Tissue Res. Vol.320, No.3, (June 2005), pp. 399-407, ISSN 1432-0878

Buchholz, D.E.; Hikita, S.T.; Rowland, T.J.; Friedrich, A.M.; Hinman, C.R.; Johnson, L.V. \& Clegg, D.O. (2009). Derivation of functional retinal pigmented epithelium from 
induced pluripotent stem cells. Stem Cells Vol.27, No.10, (October 2009), pp. 24272434, ISSN 1549-4918

Byers, M.R.; Suzuki, H. \& Maeda, T. (2003). Dental neuroplasticity, neuro-pulpal interactions, and nerve regeneration. Microsc. Res. Tech. Vol.60, No.5, (April 2003). pp. 503-515, ISSN 1097-0029

Casagrande, L.; Cordeiro, M.M.; Nör, S.A. \& Nör, J.E. (2011). Dental pulp stem cells in regenerative dentistry. Odontology Vol.99, No.1, (January 2011), pp. 1-7, ISSN 16181247

Ceonzo, K.; Gaynor, A.; Shaffer, L.; Kojima, K.; Vacanti, C.A. \& Stahl, G.L. (2006). Polyglycolic acid-induced inflammation: role of hydrolysis and resulting complement activation. Tissue Eng. Vol.12, No.2, (February 2006), pp. 301-308, ISSN 1937-3376

Chai, Y.; Jiang, X.; Ito, Y.; Bringas, P. Jr.; Han, J.; Rowitch, D.H.; Soriano, P.; McMahon, A.P. \& Sucov, H.M. (2000). Fate of the mammalian cranial neural crest during tooth and mandibular morphogenesis. Development Vol.127, No.8, (April 2000), pp. 1671-1679, ISSN 0146-0404

Chan, B.P. \& Leong, K.W. (2008). Scaffolding in tissue engineering: general approaches and tissue-specific considerations. Eur. Spine J. Suppl. 4, (December 2008), pp. 467-479, ISSN 1432-0932

Chanda, D.; Kumar, S. \& Ponnazhagan, S. (2010). Therapeutic potential of adult bone marrow-derived mesenchymal stemcells in diseases of the skeleton. J. Cell. Biochem. Vol.111, No.2, (October 2010), pp. 249-257, ISSN 1097-4644

Cordeiro, M.M.; Dong, Z.; Kaneko, T.; Zhang, Z.; Miyazawa, M.; Shi, S.; Smith, A.J. \& Nör, J.E. (2008). Dental pulp tissue engineering with stem cells from exfoliated deciduous teeth. J. Endod. Vol.34, No.8, (August 2008), pp. 962-969, ISSN 0099-2399

Cortiella, J.; Nichols, J.E.; Kojima, K.; Bonassar, L.J.; Dargon, P.; Roy, A.K.; Vacant, M.P.; Niles, J.A. \& Vacanti, C.A. (2006). Tissue-engineered lung: an in vivo and in vitro comparison of polyglycolic acid and pluronic F-127 hydrogel/somatic lung progenitor cell constructs to support tissue growth. Tissue Eng. Vol.12, No.5, (May 2006), pp. 1213-1225, ISSN 1937-3376

Crisan, M.; Yap, S.; Casteilla, L.; Chen, C.W.; Corselli, M.; Park, T.S.; Andriolo, G.; Sun, B.; Zheng, B.; Zhang, L.; Norotte, C.; Teng, P.N.; Traas, J.; Schugar, R.; Deasy, B.M.; Badylak, S.; Buhring, H.J.; Giacobino, J.P.; Lazzari, L.; Huard, J. \& Péault, B. (2008). A perivascular origin for mesenchymal stem cells in multiple human organs. Cell Stem Cell Vol.3, No.3, (September 2008), pp. 301-313, ISSN 1934-5909

d'Aquino, R.; De Rosa, A.; Laino, G.; Caruso, F.; Guida, L.; Rullo, R.; Checchi, V.; Laino, L.; Tirino, V. \& Papaccio, G. (2009). Human dental pulp stem cells: from biology to clinical applications. J. Exp. Zool. B Mol. Dev. Evol. Vol.132B, No.5, (July 2009) pp. 408-415, ISSN 1520-541X

da Silva Meirelles, L.; Chagastelles, P.C. \& Nardi, N.B. (2006). Mesenchymal stem cells reside in virtually all post-natal organs and tissues. J. Cell Sci. Vol.119, No.11, (June 2006), pp. 2204-2213, ISSN 1477-9137

Discher, D.E.; Mooney, D.J. \& Zandstra, P.W. (2009). Growth factors, matrices, and forces combine and control stem cells. Science Vol.324, No.5935, (June 2009), pp. 1673-1677, ISSN 1095-9203 
Dominici, M.; Le Blanc, K.; Mueller, I.; Slaper-Cortenbach, I.; Marini, F.; Krause, D.; Deans, R.; Keating, A.; Prockop, D.J. \& Horwitz, E. (2006). Minimal criteria for defining multipotent mesenchymal stromal cells. The International Society for Cellular Therapy position statement. Cytotherapy Vol.8, No.4, (2006), pp. 315-317, ISSN 14772566

Duailibi, M.T.; Duailibi, S.E.; Young, C.S.; Bartlett, J.D.; Vacanti, J.P. \& Yelick, P.C. (2004). Bioengineered teeth from cultured rat tooth bud cells. J. Dent. Res. Vol.83, No.7, (July 2004), pp. 523-528, ISSN 1544-0591

Duailibi, S.E.; Duailibi, M.T.; Zhang, W.; Asrican, R.; Vacanti, J.P. \& Yelick, P.C. (2008). Bioengineered dental tissues grown in the rat jaw. J. Dent. Res. Vol.87, No.8, (August 2008), pp. 745-750, ISSN 1544-0591

Duan, X.; Tu, Q.; Zhang, J.; Ye, J.; Sommer, C.; Mostoslavsky, G.; Kaplan, D.; Yang, P. \& Chen, J. (2011). Application of induced pluripotent stem (iPS) cells in periodontal tissue regeneration. J. Cell Physiol. Vol.226, No.1, (January 2011), pp. 150-157, ISSN $1097-4652$

Feng, J.; Mantesso, A. \& Sharpe, P.T. (2010). Perivascular cells as mesenchymal stem cells. Expert Opin. Biol. Ther. Vol.10, No.10, (October 2010), pp. 1441-1451, ISSN 1744-7682

Ferreira, C.F.; Magini, R.S. \& Sharpe, P.T. (2007). Biological tooth replacement and repair. J. Oral Rehabil. Vol.34, No.12, (December 2007), pp. 933-939, ISSN 1365-2842

Forsyth, N.R.; Kay, A.; Hampson, K.; Downing, A.; Talbot, R. \& McWhir, J. (2008). Transcriptome alterations due to physiological normoxic $(2 \% \mathrm{O} 2)$ culture of human embryonic stem cells. Regen. Med. Vol.3, No.6, (November 2008), pp. 817-833, ISSN 1746-0751

Fried, K.; Nosrat, C.; Lillesaar, C. \& Hildebrand, C. (2000). Molecular signaling and pulpal nerve development. Crit. Rev. Oral Biol. Med. Vol.11, No.3, (2000), pp. 318-332, ISSN $1045-4411$

Fried, K.; Lillesaar, C.; Sime, W.; Kaukua, N. \& Patarroyo, M. (2007). Target finding of pain nerve fibers: neural growth mechanisms in the tooth pulp. Physiol. Behav. Vol.92, No1-2, (September 2007), pp. 40-45, ISSN 0031-9384

Friedenstein, A.J.; Chailakhjan, R.K. \& Lalykina, K.S. (1970). The development of fibroblastcolonies in monolayer cultures of guinea-pig bone marrow and spleen cells. Cell Tissue Kinet. Vol.3, No.4, (October 1970), pp. 393-403, ISSN 0008-8730

Fristad, I.; Vandevska-Radunovic, V. \& Kvinnsland, I.H. (1999). Neurokinin-1 receptor expression in the mature dental pulp of rats. Arch. Oral Biol. Vol.44, No.2, (February 1999), pp. 191-195, ISSN 0003-9969

Fuchs, E. \& Segre, J.A. (2000). Stem cells: a new lease on life. Cell Vol.100, No.1, (January 2000), pp. 143-155, ISSN 0092-8674

Gomes, J.A.; Geraldes Monteiro, B.; Melo, G.B.; Smith, R.L.; Cavenaghi Pereira da Silva, M.; Lizier, N.F.; Kerkis, A.; Cerruti, H. \& Kerkis, I. (2010). Corneal reconstruction with tissue-engineered cell sheets composed of human immature dental pulp stem cells. Invest. Ophthalmol. Vis. Sci. Vol.51, No.3, (March 2010), pp. 1408-1414, ISSN 15525783

Griffith, L.G. \& Schwartz, M.A. (2006). Capturing complex 3D tissue physiology in vitro. Nat. Rev. Mol. Cell. Biol. Vol.7, No.3, (March 2006), pp. 211-224, ISSN 1471-0072 
Gronthos, S.; Mankani, M.; Brahim, J.; Robey, P.G. \& Shi, S. (2000). Postnatal human dental pulp stem cells (DPSCs) in vitro and in vivo. Proc. Natl. Acad. Sci. U.S.A. Vol.97, No.25, (December 2000), pp. 13625-13630, ISSN 0022-0345

Gronthos, S.; Brahim, J.; Li, W.; Fisher, L.W.; Cherman, N.; Boyde, A.; DenBesten, P.; Robey, P.G. \& Shi, S. (2002). Stem cell properties of human dental pulp stem cells. J. Dent. Res. Vol.81, No.8, (August 2002), pp. 531-535, ISSN 1544-0591

Govindasamy, V.; Abdullah, A.N.; Ronald, V.S.; Musa, S.; Ab Aziz, Z.A.; Zain, R.B.; Totey, S.; Bhonde, R.R. \& Abu Kasim, N.H. (2010). Inherent differential propensity of dental pulp stem cells derived from human deciduous and permanent teeth. $J$. Endod. Vol.36, No.9, (September 2010), pp. 1504-1515, ISSN 0099-2399

Hacking, S.A. \& Khademhosseini, A. (2009). Applications of microscale technologies for regenerative dentistry. J. Dent. Res. Vol.88, No.5, (May 2009), pp. 409-421, ISSN 1544-0591

Harada, H.; Kettunen, P.; Jung, H.S.; Mustonen, T.; Wang, Y.A. \& Thesleff, I. (1999). Localization of putative stem cells in dental epithelium and theirassociation with Notch and FGF signaling. J. Cell Biol. Vol.147, No.1, (October 1999), pp. 105-120, ISSN 1540-8140

Harichane, Y.; Hirata, A.; Dimitrova-Nakov, S.; Granja, I.; Goldberg, M.; Kellermann, O. \& Poliard, A. (2011). Pulpal progenitors and dentin repair ADR, (2011), in press, ISSN 1099-5595

Ho, S.P.; Yu, B.; Yun, W.; Marshall, G.W.; Ryder, M.I. \& Marshall, S.J. (2009). Structure, chemical composition and mechanical properties of human and rat cementum and its interface with root dentin. Acta Biomater. Vol.5, No.2, (February 2009), pp. 707718, ISSN 1742-7061

Honda, M.J.; Sumita, Y.; Kagami, H. \& Ueda. M. (2005). Histological and immunohistochemical studies of tissue engineered odontogenesis. Arch. Histol. Cytol. Vol.68, No.2, (June 2005), pp. 89-101, ISSN 1349-1717.

Honda, M.J.; Ohara, T.; Sumita, Y.; Ogaeri, T.; Kagami, H. \& Ueda, M. (2006). Preliminary study of tissue-engineered odontogenesis in the canine jaw. J. Oral Maxillofac. Surg. Vol.64, No.2, (February 2006), pp. 283-289, ISSN 1698-6946

Honda, M.J.; Tsuchiya, S.; Sumita, Y.; Sagara, H. \& Ueda, M. (2007). The sequential seeding of epithelial and mesenchymal cells for tissue-engineered tooth regeneration. Biomaterials Vol.28, No.4, (February 2007), pp. 680-689, ISSN 0142-9612

Honda, M.J.; Fong, H.; Iwatsuki, S.; Sumita, Y. \& Sarikaya, M. (2008). Tooth-forming potential in embryonic and postnatal tooth bud cells. Med. Mol. Morphol. Vol.41, No.4, (December 2008), pp. 183-192, ISSN 1860-1499

Honda, M.J.; Shinmura, Y. \& Shinohara, Y. (2009). Enamel tissue engineering using subcultured enamel organ epithelial cells in combination with dental pulp cells. Cells Tissues Organs Vol.189, No.1-4, (August 2008), pp. 261-267, ISSN 1422-6421

Honda, M.J. \& Hata, K. (2010). Enamel tissue engineering. In : « Tooth engineering » (Ed. D. Eberli). 2010, pp. 281-296, ISBN 978-953-307-079-7

Honda, M.J.; Tsuchiya, S.; Shinohara, Y.; Shinmura, Y. \& Sumita, Y. (2010). Recent advances in engineering of tooth and tooth structures using postnatal dental cells. Japanese Dental Science Vol.46 (2010), pp. 54-66, ISSN 1882-7616 
Hu, B.; Nadiri, A.; Bopp-Kuchler, S.; Perrin-Schmitt, F. \& Lesot, H. (2005). Dental epithelial histomorphogenesis in vitro. J. Dent. Res. Vol.84, No.6, (June 2005), pp. 521-525. ISSN 0022-0345

Hu, B.; Nadiri, A.; Kuchler-Bopp, S.; Perrin-Schmitt, F.; Peters, H. \& Lesot, H. (2006a). Tissue engineering of tooth crown, root, and periodontium. Tissue Eng. Vol.12, No.8, (August 2006), pp. 2069-2075, ISSN 1937-3376

Hu, B.; Unda, F.; Bopp-Kuchler, S.; Jimenez, L.; Wang, X.J.; Haïkel, Y.; Wang, S.L. \& Lesot, H. (2006b). Bone marrow cells can give rise to ameloblast-like cells. J. Dent. Res. Vol.85, No.5, (May 2006), pp. 416-421, ISSN 1544-0591

$\mathrm{Hu}$, Q.; Friedrich, A.M.; Johnson, L.V. \& Clegg, D.O. (2010). Memory in induced pluripotent stem cells: reprogrammed human retinal-pigmented epithelial cells show tendency for spontaneous redifferentiation. Stem Cells Vol.28, No.11, (November 2010), pp. 1981-1991, ISSN 1549-4918

Huang, G.T.; Sonoyama, W.; Chen, J. \& Park, S.H. (2006). In vitro characterization of human dental pulp cells: variousisolation methods and culturing environments. Cell Tissue Res. Vol.324, No.2, (May 2006), pp. 225-236, ISSN 1432-0878

Huang, G.T. (2009). Pulp and dentin tissue engineering and regeneration: current progress. Regen. Med. Vol.4, No.5, (September 2009), pp. 697-707, ISSN 1746-0751

Huang, G.T.; Gronthos, S. \& Shi, S. (2009). Mesenchymal stem cells derived from dental tissues vs. those from other sources: their biology and role in regenerative medicine. J. Dent. Res. Vol.88, No.9, (September 2009), pp. 792-806, ISSN 1544-0591

Huang, G.T.; Yamaza, T.; Shea, L.D.; Djouad, F.; Kuhn, N.Z.; Tuan, R.S. \& Shi, S. (2010). Stem/progenitor cell-mediated de novo regeneration of dental pulp with newly deposited continuous layer of dentin in an in vivo model. Tissue Eng. Part A. Vol.16, No.2, (February 2010), pp. 605-615, ISSN 1937-3376

Imbeni, V.; Kruzic, J.J.; Marshall, G.W.; Marshall, S.J. \& Ritchie, R.O. (2005). The dentinenamel junction and the fracture of human teeth. Nat. Mater. Vol.4, No.3, (March 2005), pp. 229-232, ISSN 1476-4660

Iohara, K.; Zheng, L.; Ito, M.; Tomokiyo, A.; Matsushita, K. \& Nakashima, M. (2006). Side population cells isolated from porcine dental pulp tissue with self-renewal and multipotency for dentinogenesis, chondrogenesis, adipogenesis, and neurogenesis. Stem Cells Vol.24, No.11, (November 2006), pp. 2493-2503, ISSN 1549-4918

Ishikawa, Y.; Ida-Yonemochi, H.; Suzuki, H.; Nakakura-Ohshima, K.; Jung, H.S.; Honda, M.J.; Ishii, Y.; Watanabe, N. \& Ohshima, H. (2010). Mapping of BrdU label-retaining dental pulp cells in growing teeth and their regenerative capacity after injuries. Histochem. Cell Biol. Vol.134, No.3, (September 2010), pp. 227-241, ISSN 1432-119X

Iwatsuki, S.; Honda, M.J.; Harada, H. \& Ueda, M. (2006). Cell proliferation in teeth reconstructed from dispersed cells of embryonic tooth germs in a threedimensional scaffold. Eur. J. Oral Sci. Vol.114, No.4, (August 2006), pp. 310-317, ISSN 1600-0722

Jernvall, J. \& Thesleff, I. (2000). Reiterative signaling and patterning during mammalian tooth morphogenesis. Mech. Dev. Vol.92, No.1, (March 2000), pp. 19-29, ISSN 09254773

Katz, J.L.; Misra, A.; Spencer, P.; Wang, Y.; Bumrerraj, S.; Nomura, T.; Eppell, S.J. \& TabibAzar, M. (2007). Multiscale mechanics of hierarchical structure/property 
relationships in calcified tissues and tissue/material interfaces. Mater. Sci. Eng. A Struct. Mater. Vol.27, No.3, (April 2007) pp. 450-468, ISSN 0921-5093

Kawaguchi, H.; Hirachi, A.; Hasegawa, N.; Iwata, T.; Hamaguchi, H.; Shiba, H.; Takata, T.; Kato, Y. \& Kurihara, H. (2004). Enhancement of periodontal tissue regeneration by transplantation of bone marrow mesenchymal stem cells. J. Periodontol. Vol.75, No.9, (September 2004), pp. 1281-1287, ISSN 0022-3492

Keller, L.; Kuchler-Bopp, S.; Acuna-Mendoza, S.; Poliard, A. \& Lesot, H. (2011). Tooth engineering: searching for dental mesenchymal cells sources. Front. Physio. Vol.2, (March 2011) doi: 10.3389, ISSN 1664-042X

Kerkis, I.; Kerkis, A.; Dozortsev, D.; Stukart-Parsons, G.C.; Gomes Massironi, S.M.; Pereira, L.V.; Caplan, A.I. \& Cerruti, H.F. (2006). Isolation and characterization of a population of immature dental pulpstem cells expressing OCT-4 and other embryonic stem cell markers Cells Tissues Organs. Vol.184, No.3-4, (2006), pp. 105116, ISSN 1422-6421

Kettunen, P.; Loes, S.; Furmanek, T.; Fjeld, K.; Kvinnsland, I.H.; Behar, O.; Yagi, T.; Fujisawa, H.; Vainio, S.; Taniguchi, M. \& Luukko, K. (2005). Coordination of trigeminal axon navigation and patterning with tooth organ formation: epithelial-mesenchymal interactions, and epithelial Wnt4 and Tgfbeta1 regulate semaphorin 3a expression in the dental mesenchyme. Development Vol.132, No.2, (January 2005), pp. 323-334, ISSN 1011-6370

Kim, K.; Lee, C.H.; Kim, B.K. \& Mao, J.J. (2010). Anatomically shaped tooth and periodontal regeneration by cell homing. J. Dent. Res. Vol.89, No.8, (August 2010), pp. 842-847, ISSN 1544-0591

Komine, A.; Suenaga, M.; Nakao, K.; Tsuji, T. \& Tomooka, Y. (2007) Tooth regeneration from newly established cell lines from a molar tooth germ epithelium. Biochem. Biophys. Res. Commun. Vol.355, No.3, (April 2007), pp. 758-763, ISSN 0006-291X

Kuo, T.F.; Lin, H.C.; Yang, K.C.; Lin F.H.; Chen, M.H.; Wu, C.C. \& Chang, H.H. (2011) Bone Marrow Combined With Dental Bud Cells Promotes Tooth Regeneration in Miniature Pig Model. Artf. Organs Vol.35, No.2, (February 2011), pp. 1525-1594, ISSN 1525-1594

Laino, G.; Graziano, A.; d'Aquino, R.; Pirozzi, G.; Lanza, V.; Valiante, S.; De Rosa, A.; Naro, F.; Vivarelli, E. \& Papaccio, G. (2006). An approachable human adult stem cell source for hard-tissue engineering. J. Cell Physiol. Vol.206, No.3, (March 2006), pp.693-701, ISSN1097-4652

Lesot, H.; Peterková, R.; Schmitt, R.; Meyer, J.M.; Viriot, L.; Vonesch, J.L.; Senger, B.; Peterka, M. \& Ruch, J.V. (1999). Initial features of the inner dental epithelium histomorphogenesis in the first lower molar in mouse. Int. J. Dev. Biol. Vol.43, No.3, (May 1999) pp. 245-254, ISSN 0214-6282

Lesot, H. \& Brook, A.H. (2009). Epithelial histogenesis during tooth development. Arch. Oral Biol. Vol.54, Suppl.1, (December 2009), pp. 25-33, ISSN 0003-9969

Lesot, H.; Lisi, S.; Peterkova, R.; Peterka, M.; Mitolo, V. \& Ruch, J.V. (2001). Epigenetic signals during odontoblast differentiation. Adv. Dent. Res. Vol.15, (August 2001), pp. 8-13, ISSN 0895-9374

Li, L. \& Clevers, H. (2010). Coexistence of quiescent and active adult stem cells in mammals. Science Vol.327, No.5965, (January 2010), pp. 542-545, ISSN 1095-9203 
Lisi, S.; Peterková, R.; Peterka, M.; Vonesch, J.L.; Ruch, J.V. \& Lesot, H. (2003). Tooth morphogenesis and pattern of odontoblast differentiation. Connect. Tissue Res. Vol.44, Suppl.1, (2003), pp. 167-170, ISSN 1607-8438

Lovschall, H.; Mitsiadis, T.A.; Poulsen, K.; Jensen, K.H. \& Kjeldsen, A.L. (2007). Coexpression of Notch3 and Rgs5 in the pericyte-vascular smooth muscle cell axis in response to pulp injury. Int. J. Dev. Biol. Vol.51, No.8, (2007), pp.715-721, ISSN 0214-6282

Lowry, W.E.; Richter, L.; Yachechko, R.; Pyle, A.D.; Tchieu, J.; Sridharan, R.; Clark, A.T. \& Plath, K. (2008). Generation of human induced pluripotent stem cells from dermal fibroblasts. Proc. Natl. Acad. Sci. U.S.A. Vol.105, No.8, (February 2008), pp. 28832888, ISSN 1091-6490

Lu, H.H.; Subramony, S.D.; Boushell, M.K. \& Zhang, X. (2010). Tissue engineering strategies for the regeneration of orthopedic interfaces. Ann. Biomed. Eng. Vol.38, No.6, (June 2010), pp. 2142-2154, ISSN 1350-4533

Lumsden, A.G. (1984). Tooth morphogenesis : Contribution of the cranial neural crest cells in mammals. In Belcourt A.B. \& Ruch J.V. eds, Vol.125, Colloque Inserm Paris (1984), pp. 19-27,

Luukko, K.; Moe, K.; Sijaona, A.; Furmanek, T.; Hals Kvinnsland, I.; Midtbø, M. \& Kettunen, P. (2008). Secondary induction and the development of tooth nerve supply. Ann. Anat. Vol.190, No.2, (2008), pp. 178-187, ISSN 0940-9602

Maherali, N.; Sridharan, R.; Xie, W.; Utikal, J.; Eminli, S.; Arnold, K.; Stadtfeld, M.; Yachechko, R.; Tchieu, J.; Jaenisch, R.; Plath, K. \& Hochedlinger, K. (2007). Directly reprogrammed fibroblasts show global epigenetic remodeling and widespread tissue contribution. Cell Stem Cell Vol.1, No.1, (June 2007), pp. 55-70, ISSN 1934-5909

Manning, M.L.; Foty, R.A.; Steinberg, M.S. \& Schoetz, E.M. (2010). Coaction of intercellular adhesion and cortical tension specifies tissue surface tension. Proc. Natl. Acad. Sci. U.S.A. Vol.107, No.28, (July 2010), pp. 12517-12522, ISSN 1091-6490

Manzke, E.; Katchburian, E.; Faria, F.P. \& Freymüller, E. (2005). Structural features of forming and developing blood capillaries of the enamel organ of rat molar tooth germs observed by light and electron microscopy. J. Morphol. Vol.265, No.3, (September 2005), pp. 335-342, ISSN 1097-4687

Marx, G.; Hotovely-Salomon, A.; Levdansky, L.; Gaberman, E.; Snir, G.; Sievner, Z.; Klauzner, Y.; Silberklang, M.; Thomas, D.; Hoffman, N.; Luke, S.; Lesnoy, D. \& Gorodetsky, R. (2008). Haptide-coated collagen sponge as a bioactive matrix for tissue regeneration. J. Biomed. Mater. Res. B Appl. Biomater. Vol.84, No.2, (February 2008), pp. 571-583, ISSN 1552-4981

Mitsiadis, T.A.; Fried, K. \& Goridis, C. (1999). Reactivation of Delta-Notch signaling after injury: complementary expression patterns of ligand and receptor in dental pulp. Exp. Cell Res. Vol.246, No.2, (February 1999), pp. 312-318, ISSN 0014-4827

Mitsiadis, T.A.; Roméas, A.; Lendahl, U.; Sharpe, P.T. \& Farges, J.C. (2003). Notch2 protein distribution in human teeth under normal and pathological conditions. Exp. Cell Res. Vol.282, No.2, (January 2003), pp. 101-109, ISSN 0014-4827

Miura, M.; Gronthos, S.; Zhao, M.; Lu, B.; Fisher, L.W.; Robey, P.G. \& Shi, S. (2003). SHED: stem cells from human exfoliated deciduous teeth. Proc. Natl. Acad. Sci. U.S.A. Vol.100, No.10, (May 2003), pp. 5807-5812, ISSN 1091-6490 
Morsczeck, C.; Götz, W.; Schierholz, J.; Zeilhofer, F.; Kühn, U.; Möhl, C.; Sippel, C. \& Hoffmann, K.H. (2005). Isolation of precursor cells (PCs) from human dental follicle of wisdom teeth. Matrix Biol. Vol.24, No.2, (April 2005), pp. 155-165, ISSN 0945053X

Nakagawa, E.; Itoh, T.; Yoshie, H. \& Satokata, I. (2009). Odontogenic potential of post-natal oral mucosal epithelium. J. Dent. Res. Vol.88, No.3, (March 2009), pp. 219-223, ISSN 1544-0591

Nait Lechguer, A.; Kuchler-Bopp, S.; Hu, B.; Haïkel, Y. \& and Lesot, H. (2008). Vascularization of engineered teeth. J. Dent. Res. Vol.87, No.12, (December 2008), pp. 1138-1143, ISSN 1544-0591

Nait Lechguer, A.; Kuchler-Bopp, S. \& Lesot, H. (2009). Crown formation during tooth development and tissue engineering. J. Exp. Zool. B. Mol. Dev. Evol. Vol.312B, No.2, (January 2009), pp. 399-407, ISSN 1473-2262

Nait Lechguer, A.; Couble, M.L.; Labert, N.; Kuchler-Bopp, S.; Keller, L.; Magloire, H.; Bleicher, F. \& Lesot, H. (2011). Cell Differentiation and Matrix Organization in Engineered Teeth. J. Dent. Res. Vol.90, No.5, (May 2011), pp. 583-589, ISSN 15440591

Nakao, K.; Morita, R.; Saji, Y.; Ishida, K.; Tomita, Y.; Ogawa, M.; Saitoh, M.; Tomooka, Y. \& Tsuji, T. (2007). The development of a bioengineered organ germ method. Nat. Methods Vol.4, No.3, (March 2007), pp. 227-230, ISSN 1548-7091

Nanci, A. \& Bosshardt, D.D. (2006). Structure of periodontal tissues in health and disease. Periodontol. 2000 Vol.40, (2006), pp. 11-28, ISSN 0906-6713

Nehls, V. \& Drenckhahn, D. (1991). Heterogeneity of microvascular pericytes for smooth muscle type alpha-actin. J. Cell Biol. Vol.113, No.1, (April 1991), pp. 147-154, ISSN 1540-8140

Nombela-Arrieta, C.; Ritz, J. \& Silberstein, L.E. (2011). The elusive nature and function of mesenchymal stem cells. Nat. Rev. Mol. Cell Biol. Vol.12, No.2, (February 2011), pp. 126-131, ISSN 1471-0072

Novak, A.; Shtrichman, R.; Germanguz, I.; Segev, H.; Zeevi-Levin, N.; Fishman, B.; Mandel, Y.E.; Barad, L.; Domev, H.; Kotton, D.; Mostoslavsky, G.; Binah, O. \& ItskovitzEldor, J. (2010). Enhanced reprogramming and cardiac differentiation of human keratinocytes derived from plucked hair follicles, using a single excisable lentivirus. Cell. Reprogram. Vol.12, No.6, (December 2010), pp. 665-678, ISSN 2152-4998

Ohara, T.; Itaya, T.; Usami, K.; Ando, Y.; Sakurai, H.; Honda, M.J.; Ueda, M. \& Kagami, H. (2010). Evaluation of scaffold materials for tooth tissue engineering. J. Biomed. Mater. Res. A. Vol.94, No.3, (September 2010), pp. 800-805, ISSN 1552-4965.

Ohazama, A.; Modino, S.A.; Miletich, I. \& Sharpe, P.T. (2004). Stem-cell-based tissue engineering of murine teeth. J. Dent. Res. Vol.83, No.7, (July 2004), pp. 518-522, ISSN 1544-0591

Park, C.H.; Rios, H.F.; Jin, Q.; Bland, M.E.; Flanagan, C.L.; Hollister, S.J. \& Giannobile, W.V. (2010). Biomimetic hybrid scaffolds for engineering human tooth-ligament interfaces. Biomaterials Vol.31, No.23, (August 2010), pp. 5945-5952, ISSN 0142-9612

Patel, M.; Smith, A.J.; Sloan, A.J.; Smith, G. \& Cooper, P.R. (2009). Phenotype and behaviour of dental pulp cells during expansion culture. Arch. Oral Biol. Vol.54, No.10, (October 2009), pp. 898-908, ISSN 0003-9969 
Peters, H. \& Balling, R. (1999). Teeth. Where and how to make them. Trends Genet. Vol.15, No.2, (February 1999), pp. 59-65, ISSN: 0168-9479

Pihlajamäki, H.K.; Salminen, S.T.; Tynninen, O.; Böstman, O.M. \& Laitinen, O. (2010). Tissue restoration after implantation of polyglycolide, polydioxanone, polylevolactide, and metallic pins in cortical bone: an experimental study in rabbits. Calcif. Tissue Int. Vol.87, No.1, (July 2010), pp. 90-98, ISSN 1432-0827

Pittenger, M.F.; Mackay, A.M.; Beck, S.C.; Jaiswal, R.K.; Douglas, R.; Mosca, J.D.; Moorman, M.A.; Simonetti, D.W.; Craig, S. \& Marshak, D.R. (1999). Multilineage potential of adult human mesenchymal stem cells. Science Vol.284, No.5411 (April 1999), pp. 143-147, ISSN 1095-9203

Quattrocelli, M.; Palazzolo, G.; Floris, G.; Schöffski, P.; Anastasia, L.; Orlacchio, A.; Vandendriessche, T.; Chuah, M.K.; Cossu, G.; Verfaillie, C. \& Sampaolesi, M. (2011). Intrinsic cell memory reinforcesmyogenic commitment of pericyte-derived iPSCs. J. Pathol. Vol.223, No.5, (April 2011), pp. 593-603, ISSN 0022-3417

Reilly, G.C. \& Engler, A.J. (2010). Intrinsic extracellular matrix properties regulate stem cell differentiation. J. Biomech. Vol.43, No.1, (January 2010), pp. 55-62, ISSN 0021-9290

Ripamonti, U. \& Petit, J.C. (2009). Bone morphogenetic proteins, cementogenesis, myoblastic stem cells and the induction of periodontal tissue regeneration. Cytokine Growth Factor Rev. Vol.20, No.5-6, (October-December 2009), pp. 489-499, ISSN 1359-6101

Rhodes, J.M. \& Simons, M. (2007). The extracellular matrix and blood vessel formation: not just a scaffold. J. Cell Mol. Med. Vol.11, No.2, (March-April 2007), pp. 176-205, ISSN 2136-2133

Roobrouck, V.D.; Vanuytsel, K. \& Verfaillie, C.M. (2011). Culture Mediated Changes in Fate and/or Potency of Stem Cells. Stem Cells (February 2011), doi: 10.1002, ISSN 15494918

Rothova, M.; Feng, J.; Sharpe, P.T.; Peterkova, R. \& Tucker, A.S. (2011). Contribution of mesoderm to the developing dental papilla. Int. J. Dev. Biol. Vol.55, No.1, (2011), pp. 59-64, ISSN 1696-3547

Ruch, J.V.; Lesot, H.; Karcher-Djuricic, V.; Meyer, J.M. \& Olive, M. (1982). Facts and hypotheses concerning the control of odontoblast differentiation. Differentiation Vol.21, No.1, (May 1982), pp. 7-12, ISSN 1432-0436

Ruch, J.V.; Lesot, H. \& Bègue-Kirn, C. (1995). Odontoblast differentiation. Int. J. Dev. Biol. Vol.39, No.1, (February 1995), pp. 51-68, ISSN 0214- 6282

Sakai, V.T.; Zhang, Z.; Dong, Z.; Neiva, K.G.; Machado, M.A.; Shi, S.; Santos, C.F. \& Nör, J.E. (2010). SHED differentiate into functional odontoblasts and endothelium. J. Dent. Res. Vol.89, No.8, (August 2010), pp. 791-796, ISSN 1544-0591

Salazar-Ciudad, I. \& Jernvall, J. (2004). How different types of pattern formation mechanisms affect the evolution of form and development. Evol. Dev. Vol.6, No.1, (January-February 2004), pp. 6-16, ISSN 1525-142X

Salazar-Ciudad, I. \& Jernvall, J. (2010). A computational model of teeth and the developmental origins of morphological variation. Nature Vol. 464, No.7288, (March 2010), pp. 583-586, ISSN 0028-0836

Schofield, R. (1978). The relationship between the spleen colony-forming cell and the haemopoietic stem cell. Blood Cells Vol.4, No.1-2, (1978), pp. 7-25, ISSN 1079-9796

Seo, B.M.; Miura, M.; Gronthos, S.; Bartold, P.M.; Batouli, S.; Brahim, J.; Young, M.; Robey, P.G.; Wang, C.Y. \& Shi, S. (2004). Investigation of multipotent postnatal stem cells 
from human periodontal ligament. Lancet Vol.364, No.9429, (July 2004), pp. 149-155, ISSN 0140-6736

Seo, B.M.; Sonoyama, W.; Yamaza, T.; Coppe, C.; Kikuiri, T.; Akiyama, K.; Lee, J.S. \& Shi, S. (2009). SHED repair critical-size calvarial defects in mice. Oral Dis. Vol.14, No.5, (July 2008), pp. 428-434. Erratum in: Oral Dis. Vol.14, No.4, (May 2009), pp. 302, ISSN 1601-0825

Shi, S. \& Gronthos, S. (2003). Perivascular niche of postnatal mesenchymal stem cells in human bone marrow and dental pulp. J. Bone Miner. Res. Vol.18, No.4, (April 2003), pp. 696-704, ISSN 0884-0431

Shi, S.; Robey, P.G. \& Gronthos, S. (2001). Comparison of human dental pulp and bone marrow stromal stem cells by cDNA microarray analysis. Bone Vol.29, No.6, (December 2001), pp. 532-539, ISSN 1095-9203

Shinmura, Y.; Tsuchiya, S.; Hata, K. \& Honda, M.J. (2008). Quiescent epithelial cell rests of Malassez can differentiate into ameloblast-like cells. J. Cell Physiol. Vol.217, No.3, (December 2008), pp. 728-738, ISSN 1097-4652

Siqueira da Fonseca, S.A.; Abdelmassih, S.; de Mello Cintra Lavagnolli, T.; Serafim, R.C.; Clemente Santos, E.J.; Mota Mendes, C.; de Souza Pereira, V.; Ambrosio, C.E.; Miglino, M.A.; Visintin, J.A.; Abdelmassih, R.; Kerkis, A. \& Kerkis, I. (2009). Human immature dental pulp stem cells contribution to developing mouse embryos: production of human/mouse preterm chimaeras. Cell Prolif. Vol.42, No.2, (April 2009), pp. 132-140, ISSN 0960-7722

Skinner, M.M. \& Gunz, P. (2010). The presence of accessory cusps in chimpanzee lower molars is consistent with a patterning cascade model of development. J. Anat. Vol.217, No.3, (September 2010), pp. 245-253, ISSN 1469-7580

Slavkin, H.C.; Snead, M.L.; Zeichner-David, M.; Jaskoll, T.F. \& Smith, B.T. (1984). Concepts of epithelial-mesenchymal interactions during development: tooth and lung organogenesis. J. Cell Biochem. Vol.26, No.2, (February 1984), pp. 117-125, ISSN 1097-4644

Sonoyama, W.; Liu, Y.; Fang, D.; Yamaza, T.; Seo, B.M.; Zhang, C.; Liu, H.; Gronthos, S.; Wang, C.Y.; Wang, S. \& Shi, S. (2006). Mesenchymal stem cell-mediated functional tooth regeneration in swine. PLoS One Vol.1, (December 2006), pp. 79, ISSN 19326203

Sonoyama, W.; Liu, Y.; Yamaza, T.; Tuan, R.S.; Wang, S.; Shi, S. \& Huang, G.T. (2008). Characterization of the apical papilla and its residing stem cells from human immature permanent teeth: a pilot study. J. Endod. Vol.34, No.2, (February 2008), pp. 166-171, ISSN 0099-2399

Steinberg, M.S. (1962). On the mechanism of tissue reconstruction by dissociated cells. I. Population kinetics, differential adhesiveness and the absence of directed migration. Proc. Natl. Acad. Sci. U.S.A. Vol.48, (September 1962), pp. 1577-1582, ISSN 1091-6490

Steinberg, M.S. (1963). Reconstruction of tissues by dissociated cells. Some morphogenetic tissue movements and the sorting out of embryonic cells may have a common explanation. Science Vol.141 (August 1963), pp. 401-408, ISSN 1095-9203

Sumita, Y.; Honda, M.J.; Ohara, T.; Tsuchiya, S.; Sagara, H.; Kagami, H. \& Ueda, M. (2006). Performance of collagen sponge as a 3-D scaffold for tooth-tissue engineering. Biomaterials Vol.27, No.17, (June 2006), pp. 3238-3248, ISSN 0142-9612 
Sumita, Y.; Tsuchiya, S.; Asahina, I.; Kagami, H. \& Honda, M.J. (2009). The location and characteristics of two populations of dental pulp cells affect tooth development. Eur. J. Oral Sci. Vol.117, No.2, (April 2009), pp. 113-121, ISSN 1600-0722

Takahashi, K. \& Yamanaka, S. (2006). Induction of pluripotent stem cells from mouse embryonic and adult fibroblast cultures by defined factors. Cell Vol. 126, No.4, (August 2006), pp. 663-676, ISSN 0092-8674

Takahashi, K.; Tanabe, K.; Ohnuki, M.; Narita, M.; Ichisaka, T.; Tomoda, K. \& Yamanaka, S. (2007). Induction of pluripotent stem cells from adult human fibroblasts by defined factors. Cell Vol.131, No.5, (November 2007), pp. 861-872, ISSN 0092-8674

Tamaoki, N.; Takahashi, K.; Tanaka. T.; Ichisaka, T.; Aoki, H.; Takeda-Kawaguchi, T.; Iida, K.; Kunisada, T.; Shibata, T.; Yamanaka, S. \& Tezuka, K. (2010). Dental pulp cells for induced pluripotent stem cell banking. J. Dent. Res. Vol.89, No.8, (August 2010), pp. 773-778, ISSN 1544-0591

Tavassol, F.; Schumann, P.; Lindhorst, D.; Sinikovic, B.; Voss, A.; von See, C.; Kampmann, A.; Bormann, K.H.; Carvalho, C.; Mülhaupt, R.; Harder, Y.; Laschke, M.W.; Menger, M.D.; Gellrich, N.C. \& Rücker, M. (2010). Accelerated angiogenic host tissue response to poly(L-lactide-co-glycolide) scaffolds by vitalization with osteoblastlike cells. Tissue Eng. Part A Vol.16, No.7, (July 2010), pp. 2265-2279, ISSN 2152-4955

Téclès, O.; Laurent, P.; Zygouritsas, S.; Burger, A.S.; Camps, J.; Dejou, J. \& About, I. (2005). Activation of human dental pulp progenitor/stem cells in response to odontoblast injury. Arch. Oral Biol. Vol.50, No.2, (February 2005), pp. 103-108, ISSN 0003-9969

Tian, C.; Wang, Y.; Sun, L.; Ma, K. \& Zheng, J.C. (2011). Reprogrammed mouse astrocytes retain a "memory" of tissue origin and possess more tendencies for neuronal differentiation than reprogrammed mouse embryonic fibroblasts. Protein Cell Vol.2, No.2, (February 2011), pp. 128-140, ISSN 1674-8018

Volponi, A.A.; Pang, Y. \& Sharpe, P.T. (2010). Stem cell-based biological tooth repair and regeneration. Trends Cell Biol. Vol.20, No.12, (December 2010), pp. 715-722, ISSN 0962-8924

Wang, B.; Li, L.; Du, S.; Liu, C.; Lin, X.; Chen, Y. \& Zhang, Y. (2010). Induction of human keratinocytes into enamel-secreting ameloblasts. Dev. Biol. Vol.344, No.2, (August 2010), pp. 795-799, ISSN 0012-1606

Weissman, I.L. (2000). Translating stem and progenitor cell biology to the clinic: barriers and opportunities. Science Vol.287, No.5457, (February 2000), pp. 1442-1446, ISSN 10959203

Woods, E.J.; Perry, B.C.; Hockema, J.J.; Larson, L.; Zhou, D. \& Goebel, W.S. (2009). Optimized cryopreservation method for human dental pulp-derived stem cells and their tissues of origin for banking and clinical use. Cryobiology Vol.59, No.2, (October 2009), pp. 150-157, ISSN 0011-2240

Xu, W.P.; Zhang, W.; Asrican, R.; Kim, H.J.; Kaplan, D.L. \& Yelick, P.C. (2008). Accurately shaped tooth bud cell-derived mineralized tissue formation on silk scaffolds. Tissue Eng. Part A. Vol.14, No.4, (April 2008), pp. 549-557, ISSN 2152-4955

Yang, X.; van der Kraan, P.M.; van den Dolder, J.; Walboomers, X.F.; Bian, Z.; Fan, M. \& Jansen JA. (2007). STRO-1 selected rat dental pulp stem cells transfected with adenoviral-mediated human bone morphogenetic protein 2 gene show enhanced odontogenic differentiation. Tissue Eng. Vol.13, No.11, (November 2007), pp. 28032812, ISSN 1937-3376 
Yang, Y.; Rossi, F.M. \& Putnins, E.E. (2010). Periodontal regeneration using engineered bone marrow mesenchymal stromal cells. Biomaterials Vol.31, No.33, (November 2010), pp. 8574-8582, ISSN 0142-9612

Yoshida, T.; Miyoshi, J.; Takai, Y. \& Thesleff, I. (2010). Cooperation of nectin-1 and nectin-3 is required for normal ameloblast function and crown shape development in mouse teeth. Dev. Dyn. Vol.239, No.10, (October 2010), pp. 2558-2569, ISSN 1097-0177

Young, C.S.; Kim, S.W.; Qin, C.; Baba, O.; Butler, W.T.; Taylor, R.R.; Bartlett, J.D.; Vacanti, J.P. \& Yelick, P.C. (2005). Developmental analysis and computer modelling of bioengineered teeth. Arch. Oral Biol. Vol.50, No.2, (February 2005), pp. 259-265, ISSN 0003-9969

Yu, J.; He, H.; Tang, C.; Zhang, G.; Li, Y.; Wang, R.; Shi, J. \& Jin, Y. (2010). Differentiation potential of STRO-1+ dental pulp stem cells changes during cell passaging. BMC Cell Biol. Vol.11, (May 2010), pp. 32, ISSN 1471-2121

Zippel, R.; Wilhelm, L.; Hoene, A.; Walschus, U.; Ueberrueck, T. \& Schlosser, M. (2008). Local tissue reaction and differentiation of the prosthesis-specific antibody response following functional implantation of vascular grafts in pigs. J. Biomed. Mater. Res. B Appl. Biomater. Vol.85, No.2, (May 2008), pp. 334-342, ISSN 1552-4981 


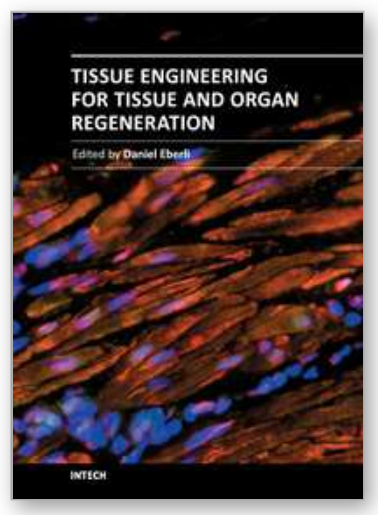

\author{
Tissue Engineering for Tissue and Organ Regeneration \\ Edited by Prof. Daniel Eberli
}

ISBN 978-953-307-688-1

Hard cover, 454 pages

Publisher InTech

Published online 17, August, 2011

Published in print edition August, 2011

Tissue Engineering may offer new treatment alternatives for organ replacement or repair deteriorated organs. Among the clinical applications of Tissue Engineering are the production of artificial skin for burn patients, tissue engineered trachea, cartilage for knee-replacement procedures, urinary bladder replacement, urethra substitutes and cellular therapies for the treatment of urinary incontinence. The Tissue Engineering approach has major advantages over traditional organ transplantation and circumvents the problem of organ shortage. Tissues reconstructed from readily available biopsy material induce only minimal or no immunogenicity when reimplanted in the patient. This book is aimed at anyone interested in the application of Tissue Engineering in different organ systems. It offers insights into a wide variety of strategies applying the principles of Tissue Engineering to tissue and organ regeneration.

\title{
How to reference
}

In order to correctly reference this scholarly work, feel free to copy and paste the following:

Sabine Kuchler-Bopp, Laetitia Keller, Anne Poliard and Herve Lesot (2011). Tooth Organ Engineering: Biological Constraints Specifying Experimental Approaches, Tissue Engineering for Tissue and Organ Regeneration, Prof. Daniel Eberli (Ed.), ISBN: 978-953-307-688-1, InTech, Available from: http://www.intechopen.com/books/tissue-engineering-for-tissue-and-organ-regeneration/tooth-organengineering-biological-constraints-specifying-experimental-approaches

\section{INTECH}

open science | open minds

\author{
InTech Europe \\ University Campus STeP Ri \\ Slavka Krautzeka 83/A \\ 51000 Rijeka, Croatia \\ Phone: +385 (51) 770447 \\ Fax: +385 (51) 686166 \\ www.intechopen.com
}

\author{
InTech China \\ Unit 405, Office Block, Hotel Equatorial Shanghai \\ No.65, Yan An Road (West), Shanghai, 200040, China \\ 中国上海市延安西路65号上海国际贵都大饭店办公楼 405 单元 \\ Phone: +86-21-62489820 \\ Fax: $+86-21-62489821$
}


(C) 2011 The Author(s). Licensee IntechOpen. This chapter is distributed under the terms of the Creative Commons Attribution-NonCommercialShareAlike-3.0 License, which permits use, distribution and reproduction for non-commercial purposes, provided the original is properly cited and derivative works building on this content are distributed under the same license. 